\title{
Full employment: a distant dream for Europe
}

\author{
Indermit Gill', Johannes Koett| $\left.\right|^{2^{*}}$ and Truman Packard ${ }^{1}$
}

\author{
* Correspondence: \\ jkoettl@worldbank.org \\ ${ }^{2}$ The World Bank and IZA, $1818 \mathrm{H}$ \\ ST NW, Washington, DC 20433, USA \\ Full list of author information is \\ available at the end of the article
}

\begin{abstract}
Today, Europe is a continent of low participation, low employment labor markets. Many observers would like to blame poor employment outcomes on the Euro or on austerity. But these are dangerous distractions from real problems that constitute imperatives for structural reform. There are differences across countries, but there is a "European model" of work: almost every European economy has more stringent employment protection and more generous social benefits than peers in North America, Oceania, and East Asia. This has led to low labor force participation and high unemployment, especially among young Europeans. Layered on top of these weak labor markets is the rapid onset of aging; if policies are not changed, Europe will lose about a million workers every year for the next five decades, especially in the 2030s. In short, Europe has to increase both the demand for and supply of labor. To do so, Europeans have to begin viewing competition as a necessary good, not an unnecessary evil. Restructuring unemployment and pension benefits will help to increase participation and reverse the decline of the workforce, but policies that promote competition for jobs and mobility of job-seekers are needed to increase the demand for labor. To get to full employment, Europe has to alter the employment protection laws that give too much power to those with jobs while marginalizing others to the fringes of the economy. Europeans will have to reduce and restructure the generous social benefits that simultaneously discourage young people from searching seriously for work and encourage older workers to quit work too early. Europeans will have to view mobility of workers as a prerequisite of European integration, not just a possible consequence of it. If all this is augmented by reforms to reduce public debt, encourage enterprise and innovation, and stabilize finance, Europe will have a vibrant economy, with high participation and full employment.

Jel codes: 138 - Government Policy; Provision and Effects of Welfare Programs, J08 - Labor Economics Policies, J21 - Labor Force and Employment, Size, and Structure, J24 - Human Capital; Skills; Occupational Choice; Labor Productivity, J32 - Nonwage Labor Costs and Benefits; Private Pensions, J42 - Monopsony; Segmented Labor Markets

Keywords: European labor markets; Segmented labor markets; Employment protection; Social benefits; Labor mobility
\end{abstract}

\section{Introduction}

In February 2000, the world watched as France instituted the 35-hour workweek, down from the 39 hours expected of French workers, and the over 40 in most developed countries. The reasoning was that because there are only so many hours of work needed, it would be better to share them among more workers. Unemployment in late 1999 was about 10 percent, so cutting the number of hours by about 10 percent might 
take care of the problem. Economists call this the "lump of labor fallacy". Another reason was the belief that French workers should be rewarded for their high productivity by allowing them to work less. Researchers found that the output per hour worked was higher in France than in almost every other country. Getting employers to pay overtime wages for work beyond 35 hours would help labor capture more benefits of high productivity.

What happened over the next few years? Unemployment did not fall by much, though the new requirements might have encouraged workers to move to smaller firms that were not covered by the law (Estevão and Sá 2008). The 35-hour workweek has since been watered down, but no government has tried to repeal it. Instead, businesses have been given ways around the problem, and the regulations have become more complicated. In the meantime, productivity growth has slowed in Western Europe and sped up in the United States. Between 1990 and 2000, output per hour worked in manufacturing-the sector with the most reliable data-grew at roughly 4 percent a year in both France and the United States. Between 2000 and 2007, it accelerated to 6 percent in the United States, while French productivity growth slowed to 3.3 percent (United States Department of Labor 2011).

Although institutions and social norms vary across Europe, the stereotype is that Americans "live to work" and Europeans "work to live". Few would argue that the two weeks of leave that many workers in the United States get is good for their productivity and growth. Americans who have traveled or lived in Europe often lament the imbalance between work and life in the United States, and attribute the rise in stress and tensions in family life to the importance Americans give to work. One could be forgiven for wondering whether in the years since Europe's "Golden Age" between 1950 and 1970, Europeans have been drifting to the opposite but equally questionable extreme. In the 1960s, the French worked the longest hours among advanced countries. By the 1980s, they worked about as long as Americans. By 2000, they worked about 300 fewer hours each year-a month and a half less-than Americans. In France, just 1 in 10 people aged 60-65 works; in the United States, the ratio is 1 in 2. It is difficult to see how norms can change so quickly; the reason has to be that policies have changed. If Europeans feel that work has declined too much, then it is obvious that policies have to change.

One development makes these decisions urgent. As people reduce the years they work in most of Europe, populations in all European countries are aging. The European Union's labor force is expected to decline by about 39 million by 2060. If the Balkans, Turkey, the Russian Federation, Ukraine, and Belarus are included, the decline is about 50 million; the projected increase of 6 million in Turkey's labor force is more than offset by the decline elsewhere. Only if actual retirement ages were to increase by around 10 years and participation rates-especially among women-were to increase to levels seen in Northern Europe, could Europe offset the decline in the labor force. None of these measures, though, would prevent the aging of the European labor force.

Europe is not alone in feeling the force of aging. Japan and other developed parts of Northeast Asia already find themselves under the strains of low fertility and increasing longevity. In the Southern Cone of Latin America, Argentina, Chile, and Uruguay are also getting old. Even China faces this challenge, and indeed will from 2015 experience faster aging than any country has experienced previously. But the most "European" 
features of the work model-unprecedented job security, generous benefits for the unemployed, and easy pension eligibility-make the imperatives created by an aging population most acute in Europe.

Europeans have a choice: work more to maintain the European social model, or give up a big part of this model through painful cuts in social benefits. The first imperative is to counter shrinking of the labor force. As in now-wealthy Western Europe, North America, and Japan, industrialization, urbanization, and advances in hygiene and health care extended lifespan and reduced child mortality and the need for large families. Yet with legal retirement age stuck at 60 or 65 in most countries, and many people retiring even younger, the number of people at work has been falling. The labor force in Europe as a whole is expected to shrink 5 percent by 2020 and more than 15 percent by 2060 .

The second imperative is to increase labor productivity. A shrinking labor force reinforces the need to develop human capital relevant in the labor market. With increasing shortages of qualified labor and rapidly changing industrial structures, any inclusive growth strategy will need to boost labor productivity through investments in human capital. Europe's adverse demography also means that its human capital has to be better leveraged. Labor market regulations, interventions, and institutions have to become more "pro-work". To ease the brakes on growth caused by aging, it is necessary to have labor market regulations that encourage more people to work, to work longer, and to work more productively. Changes that make jobs more contestable will increase productivity. And increasing the productivity of the labor force will require that Europeans become more mobile. In short, Europe will have to rid itself of the lump-of-labor fallacy that impedes smarter labor policy ${ }^{1}$.

What has to be done? First, Europe must offset the impending labor force decline by increasing the labor force participation of people of all ages. Second, European countries must improve regulations and interventions so that labor is allocated more efficiently, within and across countries. And third, Europeans will have to change their attitude to labor mobility. We arrive at these conclusions by answering three questions:

- Are employment and social protection practices reducing participation? In most parts of Europe, they are. Strict employment protection and weak work incentives undermine labor participation and efficiency in Europe. Some governments have reformed labor laws to make hiring new workers cheaper-though these changes have generally been piecemeal, as in Spain during the early 2000s-while others such as Germany have restructured social assistance schemes to make it more profitable to work rather than collect benefits. Central European countries such as Poland have changed social security systems to encourage participants to work longer, but it is far from clear whether these changes will be sustained.

- Are employment and social protection policies inhibiting efficiency? In almost all of Europe, they are. Current policies allow "insiders" to make their jobs incontestable through strict employment protection, while creating considerable work disincentives for "outsiders" through poorly designed social benefits, especially in low-wage segments. Many governments in Europe-especially in the north-have been making the labor market more contestable, and others can learn from them.

- Is Europe taking advantage of the potential for greater labor mobility? The short answer is no. Although migration between EU countries is higher than in other 
world regions, it falls short of the European Union's aspiration of a fully integrated labor market. In addition, internal labor mobility in most countries is low. The explanations (beside the obvious difference in language and culture between EU countries) involve inefficient housing markets, wage-setting practices that do not signal labor shortages and surpluses, and the absence of a Europe-wide social safety net that makes moving too risky.

Many observers would like to blame Europe's poor employment outcomes on the Euro or on austerity. But these are dangerous distractions from real problems that constitute imperatives for structural reform. What of employment and the Euro? Of the 27 member states of the European Union in March 2013, 17 use the single currency, four peg their own national currencies to the Euro, and six retain freely floating national currencies. Although the five EU countries with the highest unemployment are all Euro members (Greece, Spain, Portugal, Ireland and Cyprus), four of the five countries with the lowest unemployment rates (Austria, Luxemburg, Germany, and the Netherlands) use the single currency as well (the fifth is Romania). What about employment and austerity? This is a bit of a red herring. Greece's public spending in 2013 will be what it spent in 2002, Portugal and Italy in 2005, and Spain in 2008. The UK, France and the Netherlands have been spending a lot more. So while the headwinds on growth and demand for employment created by tighter fiscal policy cannot be ignored, nor should they distract policy makers from structural problems.

Europe is aging and its labor force shrinking. This is not news. But the speed and size of these developments is shocking, and should motivate policy responses. Labor market regulations, interventions, and institutions are restraining growth, and they must be updated. Education and training systems will need reform to enable workers to take up more productive jobs, with greater ease and to greater profit. Europeans are still less likely to move than people in other parts of the world, and the success of the single market in services depends on their becoming more mobile. To do all this, Europe's policymakers will have to convince themselves and their constituents that the rewards of hard work can be shared sensibly without treating labor as a fixed lump to be parceled out.

\section{More-and more productive-work}

Workers in Europe benefit from the most effective protection against abuse by employers and the most comprehensive job security and nonwage benefits, such as unemployment insurance, paid leave, and retirement pensions, which sustain shorter work hours than in most of the developed world. In many ways, these characteristics set Europe apart from other regions and are a triumph of economic development and liberal democracy. But given changes in Europe and the rest of the world since the end of the continent's "Golden Age" between 1950 and the mid-1970s, and the speed of global economic integration since, many features of the European work model are coming under pressure. These challenges are exacerbated by a shrinking and aging labor force.

\subsection{The decline of work}

People in many countries are working less than they used to. As countries have grown richer, people have consumed more leisure, and the average number of hours worked 
in a year has declined in most middle- and high-income countries (Figure 1). Where this reduction in hours worked is matched by gains in productivity-the output of the average worker-the decline should be expected and treated as healthy, as in Ireland, Poland, and the Slovak Republic. Yet the speed of the decline in hours worked in France, Italy, and Spain since 1995 raises concern when juxtaposed with their modest gains in labor productivity during the last two decades (Figure 2).

Several countries in Europe hold the dubious distinction of having among the lowest rates of labor participation in the world. This is a feature that marks both high- and middle-income countries in the region. The percentage of working-age people who participate in the labor market has fallen at a faster pace in several large European economies than in other member countries of the OECD (Figure 3). In Europe's southern periphery, a rare coincidence threatens future prosperity: women have low participation rates and low fertility, adding less to both today's economic output and tomorrow's.

Europeans have also been withdrawing from the labor market to retire at a much earlier age than previously (Figure 4). In France and Spain, for example, the effective age of retirement of men has fallen about twice as much as it has in Canada, Japan, and the United States. With the notable exception of the Czech Republic and Germany, where workers are staying active a bit longer than they used to, the trend in Europe is toward earlier retirement, despite efforts of governments in many countries to make qualifying for pensions more difficult. This contrasts with the gentler decline in the effective retirement age of workers in the United States, and sharply with the relative stability in the age of retirement in high-income East Asian countries. Men in the Republic of Korea, for example, are actually working almost six years longer than they were in 1965.

\subsection{The decline of populations}

Europe-the EU, EFTA, EU candidate countries, and the EU eastern partnership-will lose 50 million workers between now and $2060^{2}$. Today, the European labor force-

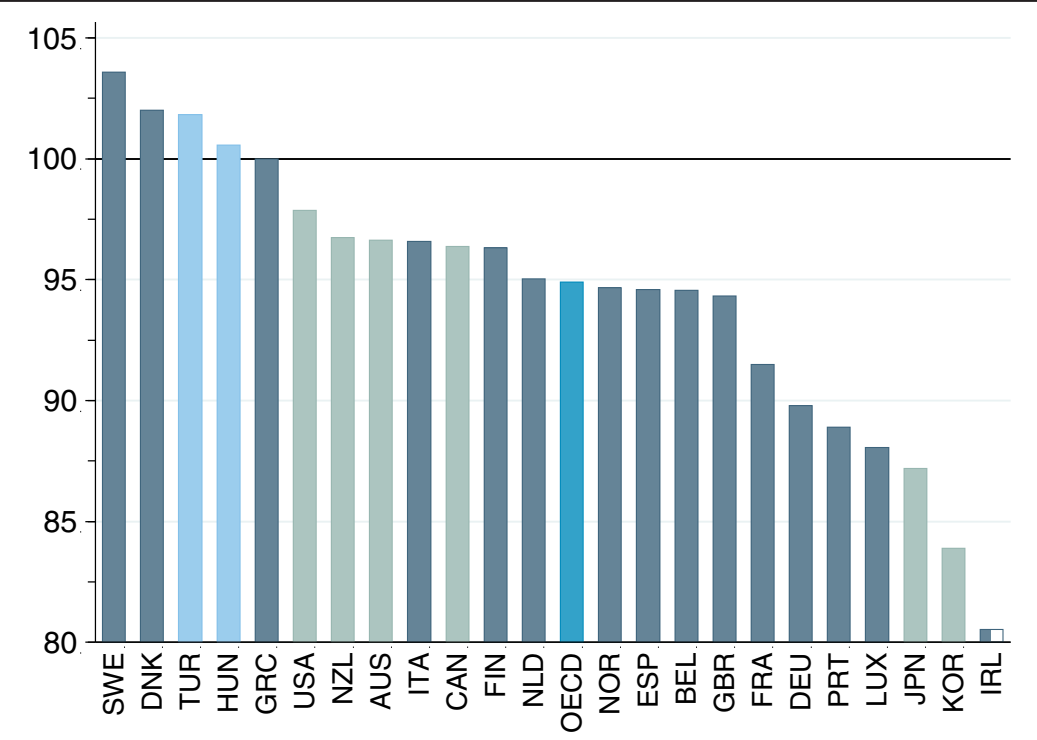

Figure 1 The decline in hours worked was faster in Europe than elsewhere in the OECD. (reported average hours worked per year, percentage point difference 1990-2008, $1990=100$ ). Source: World Bank estimates, using OECD data. 


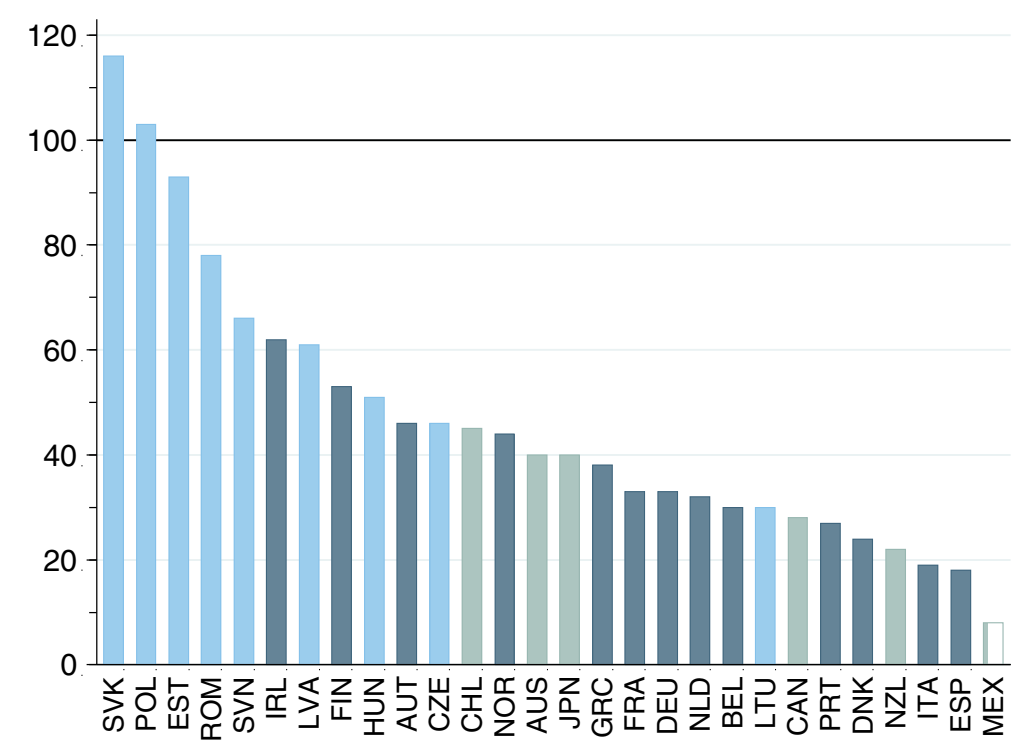

Figure 2 Europe has both productivity leaders and laggards. (GDP per hour of work, percentage point difference 1990-2008, 1990 = 100). Source: World Bank estimates, using International Labour Organization data.

employed and active job seekers-is about 320 million people; in 50 years, it will be down to 275 million, a decrease of 15 percent. Over the next 20 years, the labor force will decrease by 15 million (5 percent). Younger workers-below the age of 40-will shrink substantially during the 2020s. After 2030, the decline of the European labor force will happen among workers over 40 and gradually slow down. The largest crunch will happen during the 2030s: in that decade alone, the European labor force will fall an additional 14 million people (Figure 5).

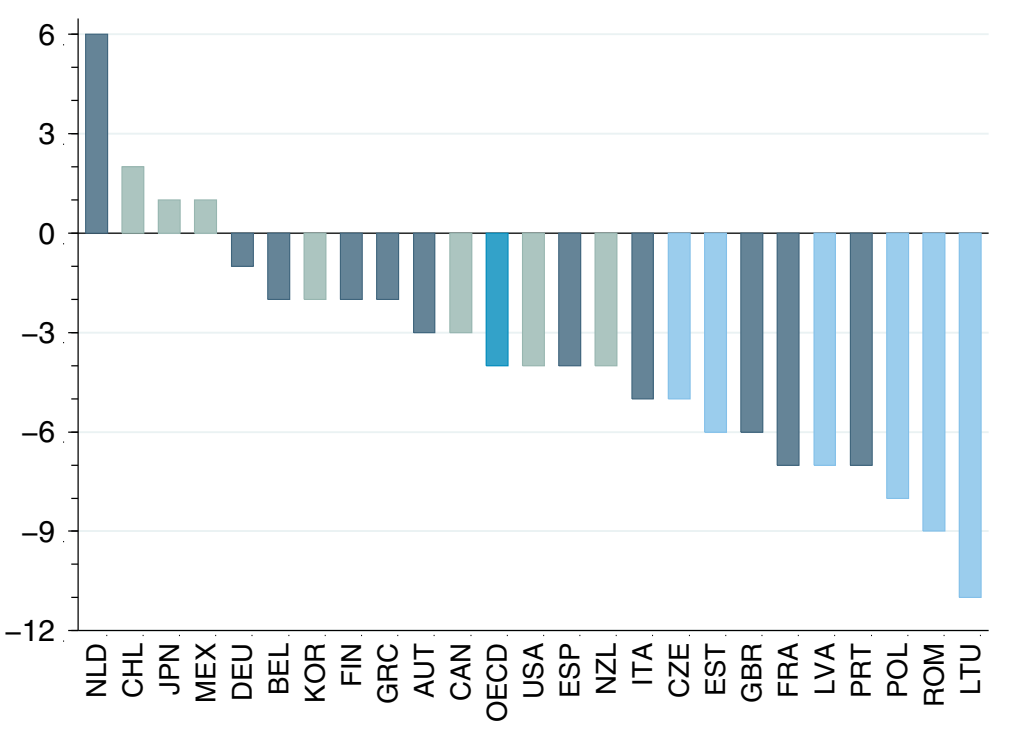

Figure 3 The decline in work participation has been faster in Europe. (change in the labor force participation of men ages 15-65, percentage point difference 1980-2008). Source: World Bank estimates, using the World Development Indicators. 


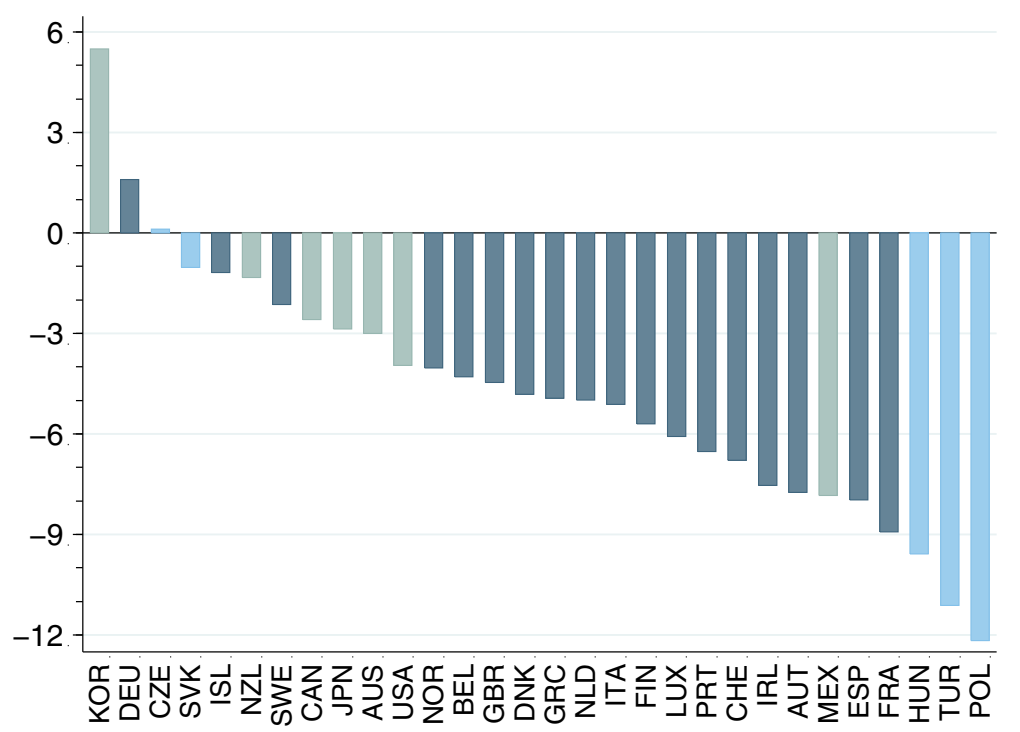

Figure 4 Europeans are retiring at earlier ages than they used to. (change in the average effective retirement age of men, number of years difference 1965-2007). Source: World Bank estimates, using OECD data.

The European Union has been facing an aging crisis since the "baby boom" generation that was born between 1945 and 1960 began retiring in 2005. The largest population cohort "Generation X," born between 1960 and 1970, will approach retirement age over the next 15 years. Generation X will start to retire in the 2020s, but thereafter, ever-smaller cohorts of young people will follow, pushing what experts call the "old-age dependency ratio" rapidly downward, so that by 2050 in some European countries there will only be two people working for every person receiving retirement pensions.

The decrease in labor force participation varies considerably across European countries. The main reason is that fertility rates in Europe range from around 1.2 to 1.5 in the Eastern, Central, and Southern European countries, to 1.6 to 2.0 in the Benelux and Northern European countries. This is lower than the demographic replacement rate of 2.1 required to keep the size of the population stable.

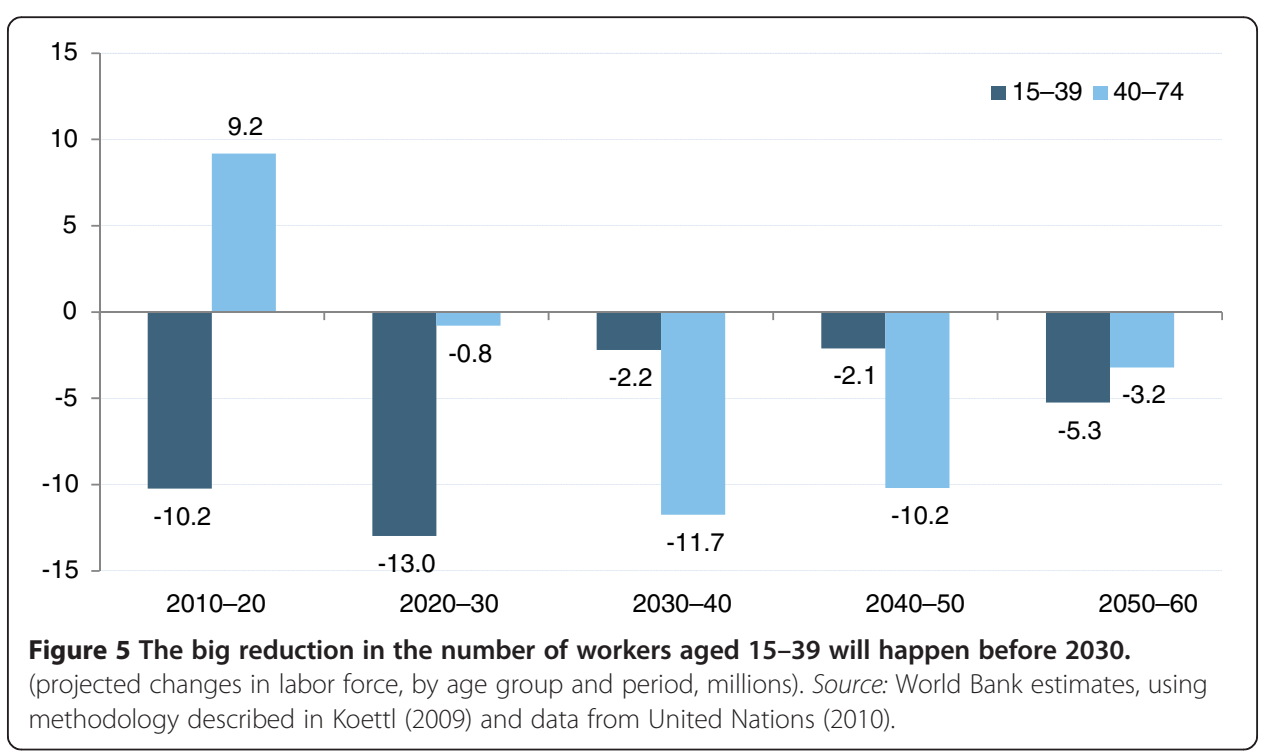


The fall in the labor force will be particularly severe for EU and EFTA countries. Their labor force will decrease by 39 million people (18 percent) over the next 50 years. The other eastern European countries do not fare much better, with an equally steep decline of 16 percent. The only exception is Turkey, where the labor force is projected to increase 12 percent until 2060.

The natural consequence of falling fertility and rising longevity is an increase in the old-age dependency ratio-the number of people older than 65 relative to those of working age (15-65). By 2050, this ratio will double to about 50 percent in Europe, with Spain (68), Italy (66), and Portugal (58) projected to have the highest ratios (Muenz 2007). The projected changes in Europe-especially Southern and Eastern Europe-contrast with trends south of the Mediterranean, where the population is still fairly young.

\subsection{Improving Europe's demographic arithmetic}

Can Europe mitigate these trends? Only with radical policy and behavioral changes. If participation rates in all countries were to converge to those seen in Northern Europe or if work lives were to expand by 10 years across the board, the European labor force would actually increase by 2060 (by 5 percent and 2 percent, respectively; Figure 6). If female labor force participation were to converge to that of men, the labor force would still decrease, but only by 5 percent, as opposed to 15 percent in the baseline scenario. None of these scenarios counteracts the loss of young workers due to continually decreasing younger-age cohorts. Under all four scenarios-including the combined maximum scenario-the labor force below age 40 will shrink. In other words, the only large pool of potential additional workers-apart from new immigrants-that Europe could draw from in the future is among the elderly (ages 65 and older).

Given the low participation rates in many European countries-especially among women, youth, the elderly, and excluded groups-there is room to improve and to stem some of the decline of the European labor force. To encourage people to participate, incentives for work must be aligned to ensure that work pays for both the employee and the employer. This could require, among other policy reforms, significant changes on labor taxation and social benefit design.

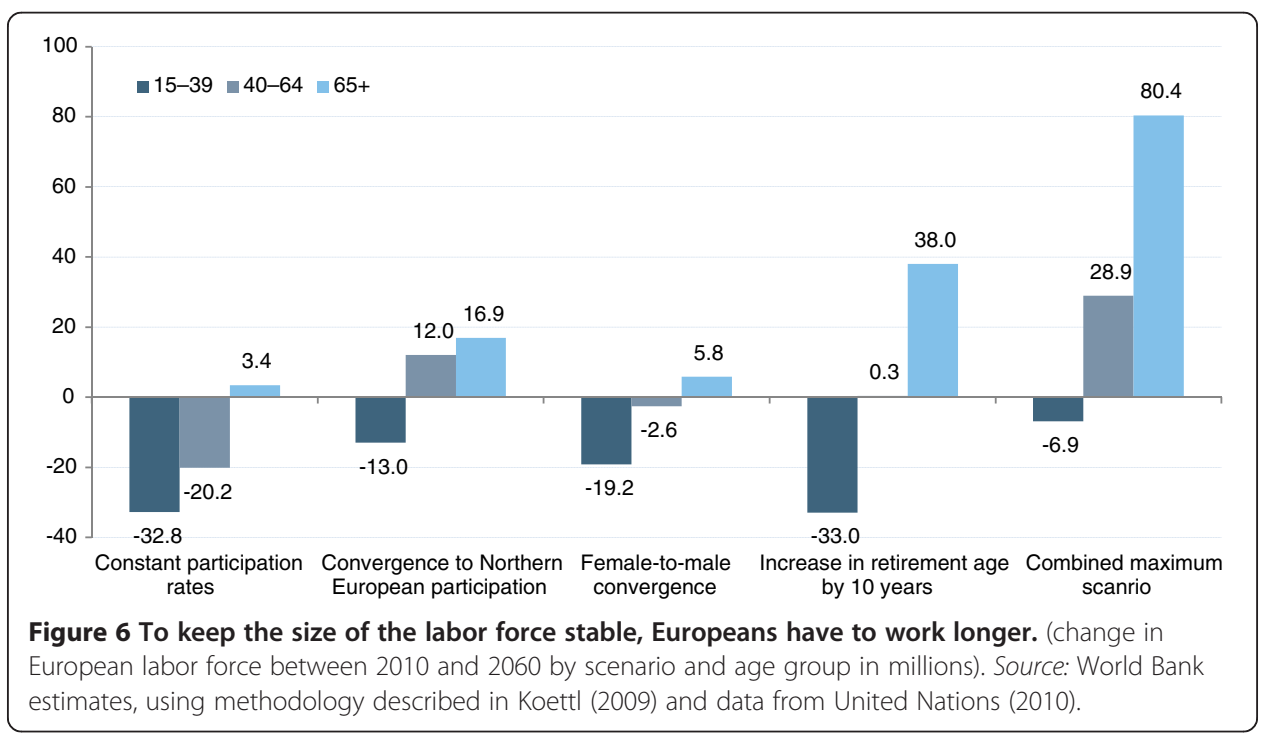


Women constitute 50 percent of the working-age population and given that they are increasingly more educated-more than men among younger cohorts-they represent a large pool of untapped talent. Even if their entry into the market in larger numbers does not produce the payoff in additional workers that comes from increasing the retirement age, it could have a large productivity payoff. Increasing female labor force participation would require interventions that allow women to better juggle multiple roles by providing, for example, child care facilities and flexible work arrangements (World Bank 2010b). The latter might also play an important role for keeping elderly workers in the labor force by allowing them to phase in retirement on a part-time basis.

To increase labor force participation across the board, both employees and employers need the right incentives for work. Currently, it seems that disincentives for (formal) work are substantial in many European countries, especially for low-productivity workers. For example, Koettl (2013) and Koettl and Weber (2013) show that when comparing formal jobs with informal jobs, the benefits of formal jobs would have to be quite large to offset their costs in terms of taxes, social security contributions, and withdrawn social benefits. A similar result might hold for a comparison between formal jobs and inactivity. This leads to the conclusion that formal (part-time) jobs at low wage levels may not be an economically viable option for low-productivity job seekers in many European countries. For employers, high labor taxation has similar implications as it increases the total costs of labor and makes it less attractive to hire. Analysis using EU-Statistics on Income and Living Conditions data suggests that there is a negative correlation between the incidence of formal employment and work disincentives at the individual level (Koettl and Weber 2013).

Two main levers can make (formal) work pay for low-productivity workers and their employers: decreasing the labor tax wedge at lower wage levels and "smoothing" incentives with changes to social assistance, housing, and family benefits. Regarding the tax wedge, current social protection financing in several countries discriminates against lower earners. Options for reducing the labor tax wedge include incentives linked to wage subsidies, social insurance contribution credits, or so-called "in-work" or employment-conditional benefits-cash benefits or refundable income tax credits conditional on formal employment-for low-wage earners. With regard to the design of social assistance, housing, and family benefits, the key is to keep the marginal effective tax rate in mind when designing eligibility conditions and how benefits are withdrawn. The goal is to reform these benefits toward so-called "smart safety nets," making social protection benefits more compatible with work. In particular, any additional wage should also increase beneficiaries' net incomes, including benefits. Otherwise, additional work does not pay, and beneficiaries will prefer to not work at all, to work informally, or to underreport their earnings ${ }^{3}$.

\subsection{Developing the skills to work to potential}

Recent studies from the OECD spotlight the importance of skills-cognitive, socioemotional, technical-in determining productivity. For example, Hanushek and Woessmann (2008) have shown that cognitive skills (proxied by Program for International Student Assessment scores) explain a sizeable part of the variation in growth rates observed in OECD countries, including Western Europe ${ }^{4}$. In fact, the evidence suggests that generic skills also have substantial growth payoffs, even in advanced economies. Unsurprisingly, 
skills are at the center of the policy agenda of the European Union and Europe at large, as reflected in the European Union's growth strategies (Lisbon Agenda, Europe 2020) and numerous strategic and policy documents (European Commission 2010a; World Bank 2011a).

Skills include not only technical ability, but also generic cognitive skills (literacy, numeracy, problem solving) and generic noncognitive skills (socioemotional and behavioral attributes such as team work, self-discipline, and perseverance). A solid base of generic skills seems to be a prerequisite for further acquisition of technical skills, whether through post-secondary education or on the job ${ }^{5}$. Further, the foundation for the development of generic skills is built early in life and during adolescence and hinge on having access to adequate nutrition, nurturing environments, and the quality of basic education (World Bank 2010a).

Skills not only matter for economy-wide productivity but also individual labor market outcomes. Differences in labor force participation rates between those with tertiary education and those with less than upper secondary education range from about 8 percentage points in Iceland to 28 percentage points in Turkey (Figure 7). In other words, in Turkey the higher educated are 28 percent more likely to participate than those with lower education. In Bulgaria, Romania, and Serbia, the share of the Roma working-age population with at least some secondary education is 60 percentage points lower than that of the non-Roma. In some countries, the Roma could be a quarter of potential new labor market entrance in the near future. Helping them and other excluded groups-like ethnic minorities or first and second generation immigrants-become more productive is not only a matter of social inclusion; it could also increase economic growth (World Bank 2010b).

Firm surveys show that skills shortages have in recent years become increasingly binding for enterprise productivity and job creation in emerging Europe. Skilled labor

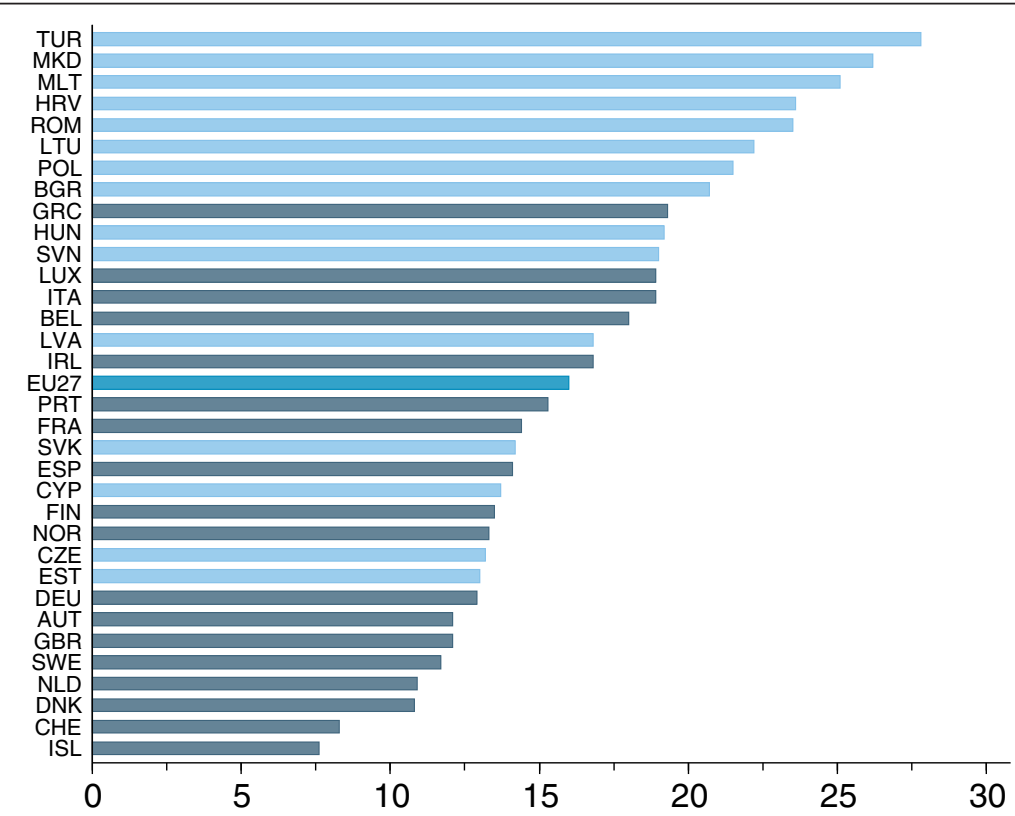

Figure 7 More educated people participate more in the labor market. (percentage-point difference in labor force participation rates between those with tertiary education and those with less than upper secondary education, 2010). Source: World Bank estimates, based on Eurostat (2011). 
shortages have become the second-most commonly reported constraint to growth in the enterprise surveys across all countries in Eastern Europe, behind only tax rates (World Bank 2010a). On average, 30 percent of firms considered education and skills to be a major or severe constraint in 2008. Upwards of 40 percent of firms were dissatisfied with the availability of skilled workers in the former Yugoslav Republic of Macedonia and Ukraine. These surveys have found that in addition to technical skills, the lack of noncognitive generic skills appears especially binding (World Bank 2009, 2010a). Also in OECD countries and some middle-income countries, noncognitive skills are as important as cognitive and technical skills in firms' hiring decisions ${ }^{6}$.

Despite overall success in increasing student enrollment, the quality of education needs to be improved. The picture of education quality in Europe is diverse. Outcomes-as measured by the Program for International Student Assessment-appear particularly poor in Azerbaijan, Bulgaria, Montenegro, and Romania, which have students in early grades that underperform relative to the country's level of development (Figure 8). For another group of countries (Bulgaria, Croatia, Czech Republic, and FYR Macedonia), the performance in cognitive tests worsened between 2006 and 2009. Worrisome for labor market outcomes, upper secondary and tertiary education students may be graduating with the wrong skill sets (World Bank 2010a). There is evidence that after the transition, the obsolescence of technical skills was not addressed and that vocational education systems have not performed well. As a result, employers today often assert that it is difficult to find graduates with adequate technical skills.

Effective policy interventions can address many of these problems. Interventions should focus on overcoming failures in information and quality assurance. Countries should also rethink their training and education systems to avoid specialization in narrow (technical) fields too early in a student's career. The dual apprenticeship systems of Austria, Germany, and Switzerland are often cited as a role model to combine vocational education with employer-driven on-the-job learning, resulting in the creation of highly relevant skills and successful work careers. Yet, as has been pointed out by

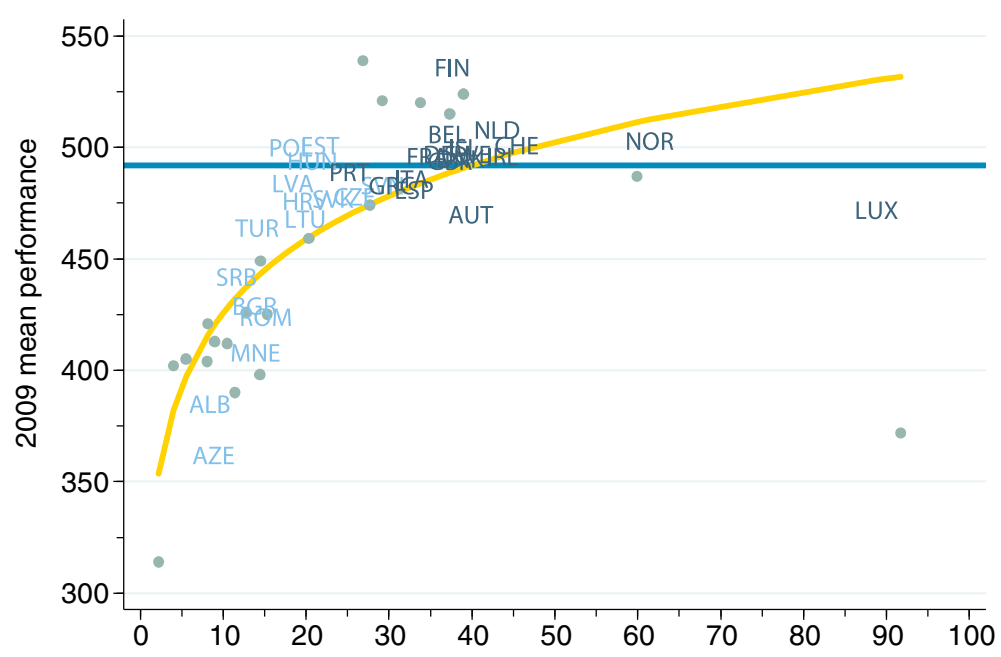

Figure 8 Cognitive skills are adequate in Europe, but some countries are lagging. (reading competency of 15-year-olds on the PISA 2009 by income levels of countries). Note: The figure shows a log-linear regression line representing countries' predicted Program for International Student Assessment reading scores based on their GDP per capita. The blue line is the OECD mean reading score. Source: World Bank 2011. 
Eichhorst and Marx (2009), for these systems to be successful a whole set of policies, ranging from social protection and employment protection to production regulations have to be mutually reinforcing. And although these systems might work well in highly specialized manufacturing, they might work less well in the relative low-skilled service sector. Countries should also ensure that preschool and basic education curricula and pedagogic practice pay adequate attention to the development of cognitive and noncognitive skills.

\section{Making jobs contestable}

The main rationale for the government's role in the labor market is to protect workers from a lack of competition among employers for their labor and human capital. Yet many of the prevailing models of policy intervention are from a time in Europe's history when large-scale manufacturing dominated economies and a few (and in some places even single) employers could set the price of labor and manage their human resources with impunity. Images come to mind of the abuses in Victorian-era Britain, where workers toiled for 14-hour shifts and could be dismissed at the employer's whim. The balance of information and power between those who seek jobs and those who offer them has shifted considerably in the decades since. And along with this shift, the changing economic structure of most European countries-away from large-scale industry toward varied services-has made the labor market more "atomistic". As more services become tradable, it is harder for employers and workers to avoid competition.

Labor market policies in Europe have not kept up with these changes. The policies prevalent in much of Europe-and parts of the world that Europeans trade and compete with-make its labor markets more difficult to contest, especially for new, younger entrants. This lack of contestability may discourage some from entering the labor market, impede the efforts of others to match up with employers who could most benefit from their skills and attitudes, and increase the incidence and duration of unemployment. Recent evidence shows that in countries where the labor market is less contestable-especially due to restrictions on dismissal-individuals and firms are more likely to take their activities into the shadows of unregulated and untaxed markets, depriving the state and society of public goods and holding back economies from fulfilling their growth potential (Hazans 2011; Packard et al. 2012).

Does it matter if Europe's labor markets are less contestable? The broad divergence in the speed that employment is recovering in the wake of the global financial crisis and recession suggests that it does. In countries that forgo the macroeconomic shockabsorber offered by a flexible exchange rate (that is, all current euro area members and those preparing to join by tying their currencies to the euro), the impact of a sudden fall in demand on the product and labor markets can be mitigated if wages are allowed to fall, hours are flexible, and workers at the margin can be dismissed.

When examining the relationship between labor market structures and outcomes, it is helpful to distinguish between regulations, interventions, and institutions. Regulations set work's legal parameters, in the form of a minimum wage and/or restrictions on dismissal. The state deploys interventions to correct market failures, such as the inability of private financial markets to viably insure the risk of unemployment (unemployment insurance) and differences in how much information employers and job seekers have (job-seeking assistance). Institutions are the structures and agreed procedures for exerting influence and 
carrying out decisions. For the labor market, the best example is the space afforded in the legal code of most countries for collective bargaining through labor unions.

\subsection{Hiring and firing workers is too costly}

A legislated minimum wage or other nonmarket floor on salaries increases labor costs for firms and can dissuade them from offering employment to workers whose marginal productivity does not exceed the minimum. This effect will be stronger for workers with lower productivity, especially younger, unskilled, less experienced workers (Montenegro and Pagés 2005). Priced out of jobs on the formal (regulated and taxed) market for labor, they can join those genuinely unemployed, take an informal (unregulated and untaxed) job, or pretend to look for a job while working informally. But a minimum wage might also motivate workers to increase productivity in the "efficient wages" framework, or persuade job seekers and some outside the labor market to hold out for a job on the formal market, even if plenty of informal employment is on offer (Rebitzer and Taylor 1995; Manning 1995).

All new members of the European Union introduced legislated minimum wages. Although several older members do not have legally binding minimum wages, an effective minimum wage is secured through the collective bargaining process in Austria, Denmark, France, Germany, Italy, and Sweden. Generally, legislated minimum wages in the European Union's new members are considerably lower than the legislated or effective minimum wages in the older member states. Over the past decade, however, these have been on a clear upward trend. Since 2000, the minimum wage as a percentage of average wages has risen fastest in Bulgaria and the Czech Republic.

A second common set of labor laws, employment protection legislation (EPL), restricts employers' ability to dismiss workers-reducing flows into unemployment but also out of it. Strict EPL can slow new employment if restrictions on dismissing workers make employers wary of hiring someone new. For this reason, restrictions on dismissal can increase unemployment, the duration of unemployment, and the attraction of fixed-term contracts. Past a certain threshold, it can even cause employers to turn to the untaxed, unregulated labor market. Beyond affecting flows into and out of employment, EPL creates an "insideroutsider" divide. Those that have a protected job ("insiders") are relatively guarded from losing it, while the inactive and unemployed ("outsiders") find it more difficult to gain employment. EPL changes the distribution of jobs with important implications for first-time job seekers, youth (especially), women, the disabled, and other disadvantaged groups.

Using the OECD's (2004) measure of the strictness of employment protection-and its application by Lehmann and Muravyev (2010) to non-OECD European countries-the least restrictive conditions for employers are in Denmark, Hungary, Ireland, and the Slovak Republic. France, Greece, Portugal, and Spain have the most restrictive regulations. In Austria, Greece, Italy, Portugal, the Slovak Republic, and Spain employment protection has been noticeably relaxed. Partly, this relaxation has come in the form of more temporary contracts, especially in Italy and Spain (see below). But over the same period, Hungary, Ireland, and Poland have tightened their EPL. EPL in the European Union's newest member states is lower than in the older members, but there has been convergence driven both by liberalization in parts of the west and growing restrictions among members in the east. Lithuania and Slovenia had the most restrictive legislation, though Slovenia has liberalized recently. Romania, by contrast, recently tightened its EPL and, after Portugal and Spain, now has the most restrictive regulation. 
During the past decades, EPL reform in Europe was mostly "partial" or "two-tier". In the mid-1980s, several European countries, characterized by high levels of EPL, introduced temporary contracts to increase labor market flexibility. Since then, most accessions to employment have been through fixed-term contracts. Many countries deregulated the use of temporary contracts substantially but maintained strict protection for permanent ones. There is substantial literature on these reforms, based largely on the Spanish experience (Dolado et al. 2002; Bentolila et al. 2008). Because temporary contracts involve much lower firing costs, both in severance payments and legal costs, their incidence increased significantly. According to the European Commission (2010c), EU member states that introduced large two-tier EPL reforms have seen an increase in temporary employment since the mid1980s. Countries with relatively less stringent regulations for permanent contracts-like Denmark, Ireland, and the United Kingdom-do not show any trend increase in the incidence of temporary employment.

Temporary contracts affect young workers more. In most EU member states, 40 percent of young people (ages 15-39) are on temporary contracts, especially among those under 25 years of age. The share of temporary employment among workers in the 15to-24 age group ranges from more than 50 percent in countries like France, Germany, Poland, Slovenia, and Spain to less than 20 percent in Bulgaria, Czech Republic, Latvia, Lithuania, Romania, the Slovak Republic, and the United Kingdom.

Temporary contracts have both positive and adverse effects. They can help firms to evaluate workers' suitability for jobs. In that sense, temporary jobs could act as a stepping stone to more stable jobs. The recent debate in the literature around so-called "single contracts" intends to develop policy proposals that strengthen this aspect of temporary contracts. These single contracts afford higher EPL with longer tenure, leading to a convergence to permanent contracts over time (see, for example, Blanchard and Tirole 2003; Cahuc and Kramarz 2004; García Pérez and Osuna 2011). Temporary contracts could also act as a shock absorber, protecting firms from temporary demand fluctuations by avoiding costly adjustments to their core labor force. Boeri and Garibaldi (2007) and Boeri (2011) show that the "flexibility at the margin" provided by temporary contracts increases both hiring and firing rates for newly created jobs as firms try to restrict firing costs through reduced conversion. At the same time, a large segment of workers on temporary contract can exasperate fluctuations in the unemployment rate during recessions, as shown by Bentolila et al. (2012) for the case of Spain. Of course, temporary contracts can also simply be an easy way for firms to reduce labor costs, substituting temporary for permanent workers, leading to dualistic labor markets (Layard 2005).

Overall, the experience with piecemeal reforms like the one in Spain suggests that the two-tier EPL led to an increase in turnover, a reduction in long-term unemployment, and greater employment. But is also is associated with a fall in investment in firm-specific skills and a decrease in labor productivity. Temporary contracts can help make labor markets more dynamic. Two-tier EPL reforms have dramatically raised the proportion of new recruitments of temporary contracts (Cahuc and Postel-Vinay 2002). Bover and Gomez (2004) found that in Spain, exit rates from unemployment into temporary contracts were 10 times larger than exit rates into permanent ones between 1987 and 1994.

The effects of EPL reforms on unemployment are also important. Using a sample of large Spanish firms in 1993-94, Garcia-Serrano (1998) found that turnover rates varied significantly by type of employment contract. In particular, a rise of one percentage 
point in the share of temporary employment increased flows from employment to unemployment, unemployment to employment, and employment to employment by 0.26 percentage points. Bentolila et al. (2008) found that, insofar as the use of temporary contracts implies a rise in the hiring rate, they have helped decrease long-term unemployment, especially in periods of high growth.

While helping to create labor market dynamism and employment, temporary contracts can adversely affect productivity and investment in skills. Greater turnover and low conversion rates can reduce incentives to invest in firm-specific human capital (Dolado et al. 2002; Bentolila et al. 2008). Guell and Petrongolo (2007) argue that the negative impact of temporary work on vocational training depends on whether temporary contracts are used mainly to lower wage costs or to screen for entry-level jobs. Boeri and Garibaldi (2007) found that the share of temporary workers in Italy has a large negative impact on firm-level productivity growth. The authors argue that rising employment, in the aftermath of two-tier EPL reforms, led to falling labor productivity through decreasing marginal returns for labor.

Labor market interventions- "active" labor market programs such as training and job search assistance, and "passive" unemployment benefits such as unemployment insurance and other forms of social insurance-are common in the European Union, including the new member states. These interventions are typically financed directly through a tax on earnings. In much of Europe, the cost of these interventions raises the cost of labor, creating a "tax wedge" between what employers pay for work and what workers take home (Figures 9 and 10). The largest component of the tax wedge comes as personal income tax and contributions to pensions and health insurance, but financing these interventions also adds to labor costs. A higher tax wedge contributes to higher labor costs in the formal sector and can dissuade employers from taking on workers or

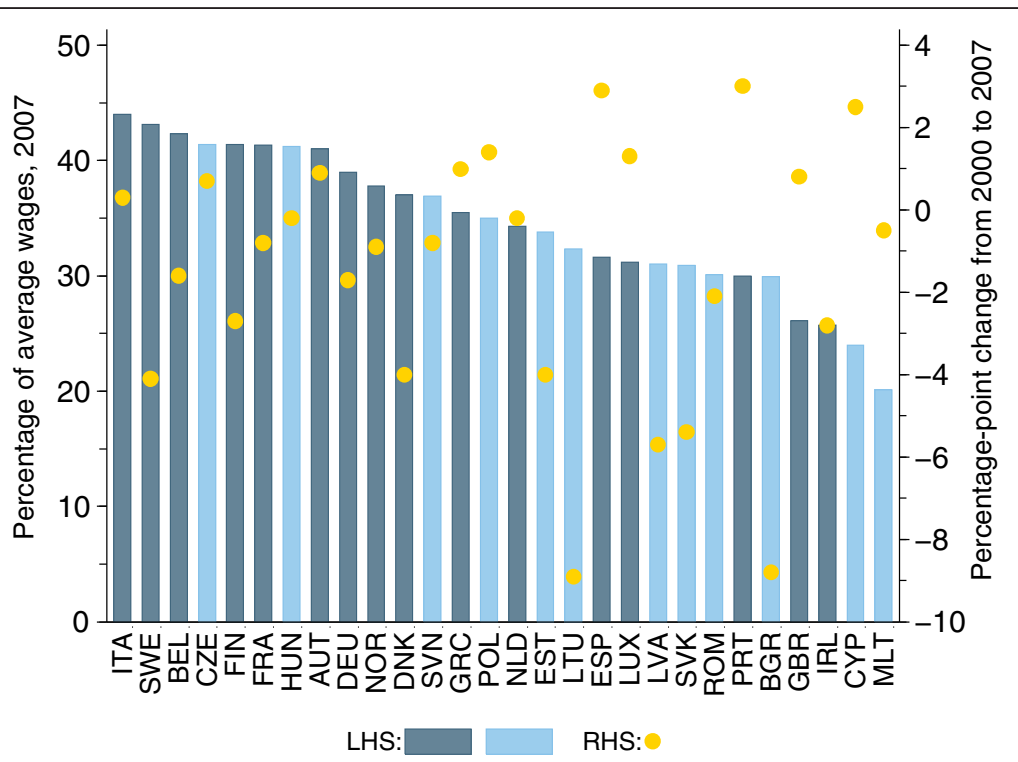

Figure 9 The wedge created by income taxes and social insurance contributions is highest in Italy. (average personal income tax and social security contributions [employer and employee] on gross labor income, 100 percent of average wage for a person without a partner and no children). Source: World Bank estimates, using OECD and Institute for the Study of Labor data. Note: Dark blue bars represent Western Europe, and light blue emerging European economies. 


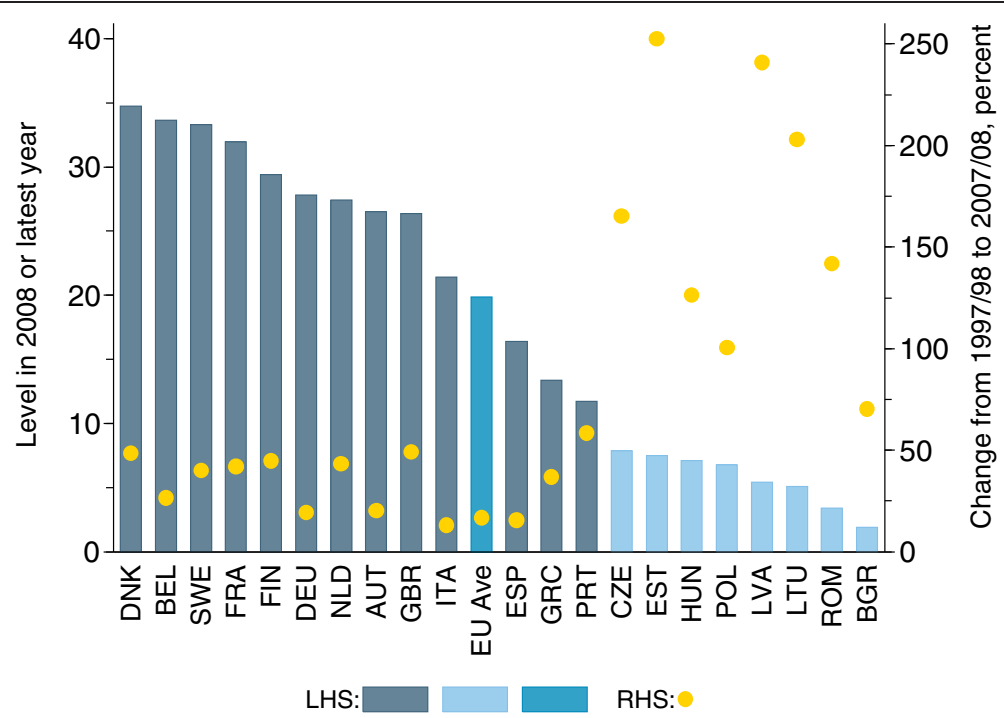

Figure 10 Labor costs have been rising quickly in the EU's newer members. (average hourly labor costs, calculated as cost of labor divided by hours worked). Source: World Bank estimates, using Eurostat data.

increase demand for informal ways of contracting workers (Davis and Henrekson 2004). Not only is the level of labor taxation important, but also how it progresses over income levels. In the new member states of Eastern Europe, labor taxation tends to be high on low-wage earners, potentially making it more difficult for them to work in the formal sector. Moreover, the wage level at which labor taxes start to increase is also fairly high, making labor taxation less progressive in these countries (Koettl and Weber 2013).

When well-designed and administered, such programs may improve labor market performance. Active programs that enhance skills or eliminate information asymmetries that delay or frustrate matching in the labor market should shorten the job search period. Active programs might lower the search and training costs of firms and indirectly subsidize the creation of better jobs. Passive programs, such as unemployment benefits, can remove the urgency of finding a new job and improve the quality of matches. But the record of active programs is mixed at best (Card et al. 2010), and if unemployment benefits are overly generous or poorly designed, they can lower peoples' motivation to look for and accept a job (Holmlund 1998).

Finally, it is difficult to isolate institutions that impact only the labor market from those that also shape other social and economic interactions. One is especially relevant: collective bargaining as proxied by the strength of labor unions. The impact of labor unions is felt largely through the importance of minimum wages, EPL, and active and passive interventions already discussed (Figure 11). But strong labor unions can shape the labor market beyond the direct impact of regulation and interventions. For example, even where the share of the total labor force that is unionized is small, it may be high in certain key sectors, such as public administration and the provision of essential services including education, health, and transportation. The labor code in some countries even augments collective bargaining and the power of unions: the salaries and benefits unions succeed in negotiating for their members can become binding for others in regulated employment, whether they are members or not ${ }^{7}$. 


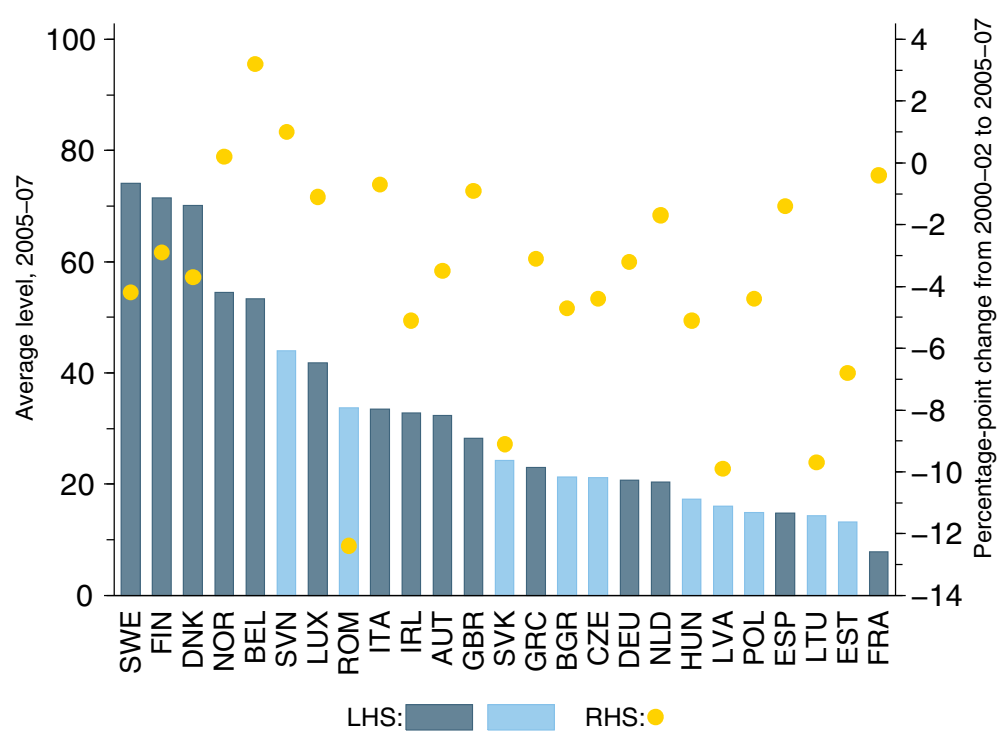

Figure 11 In much of the European Union, membership in labor unions has been declining. (percentage of workers who belong to a labor union, 2000 to 2007). Note: Dark blue bars represent Western Europe, and light blue emerging European economies. Source: World Bank estimates, using OECD and Institute for the Study of Labor data.

\subsection{Work is being pushed out of (regulated) markets}

Taxes and regulations can create incentives for people to consume more "own-provided" services at home and for workers and employers to transact "in the shadow" on the unregulated and untaxed market (Rosen 1997; Davis and Henrekson 2004; Packard et al. 2012). The likelihood that they will transact informally increases where a government's capacity to enforce regulation is low. Conventional textbook models show how restrictions on firing, a relatively high minimum wage, and the taxes on labor that finance active and passive assistance programs can segment insiders who benefit from the labor code from outsiders who cannot. Less conventionally, in countries where governments fail to provide or sustain high-quality services, employers and workers can become disenchanted with complex labor regulation and consider taxes and compliance efforts not worthwhile. There is evidence that high taxes increase nonmarket or home production of services in Northern Europe, and they push legal market activities into the informal market in the south (Figure 12).

\subsection{What helps, what hurts}

Because there is no simple mapping between labor market outcomes and labor market and social protection policies, a more rigorous analysis of the links between the two is needed, controlling for country characteristics. Country-level data from the OECD, Institute for the Study of Labor, International Labour Organization, and European Bank for Reconstruction and Development can be used to assess how the institutions, regulations, and interventions discussed above are associated with the performance of Europe's labor markets relative to other countries ${ }^{8}$. This approach is fraught with estimation problems, and the results should be interpreted as indicative correlations rather than causal relationships ${ }^{9}$. It also compliments the firm-level analysis provided in chapter 4 of Gill and 


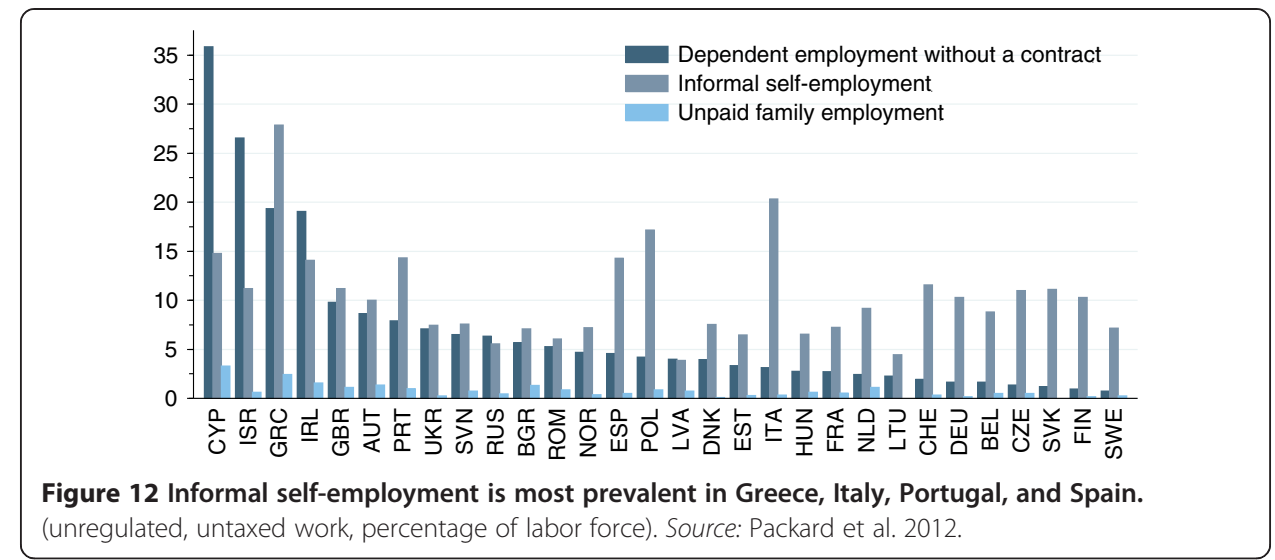

Raiser (2012), focusing on country-level legal and institutional variables, which are not captured in that analysis. The cross-country analysis also complements microeconomic evidence at the individual level when analyzing disincentives for formal work originating in the tax and benefit system, as discussed in the subsection on work disincentives (Koettl and Weber 2013).

Fialová (2011) examines the impact of regulation, interventions, and institutions on three indicators of labor market performance: the activity rate (AR); employment rate (ER); and the unemployment rate $(\mathrm{UR})^{10}$. This is done for three sets of countries: the European Union and other OECD members ${ }^{11}$, the European Union ${ }^{12}$, and EU new member states, accession countries, and others in the European neighborhood (Figures 13, 14 and 15) ${ }^{13}$.

With regard to employment protection, stricter EPL is mostly associated with lower participation rates-except in Western Europe-and higher unemployment rates. Similarly,

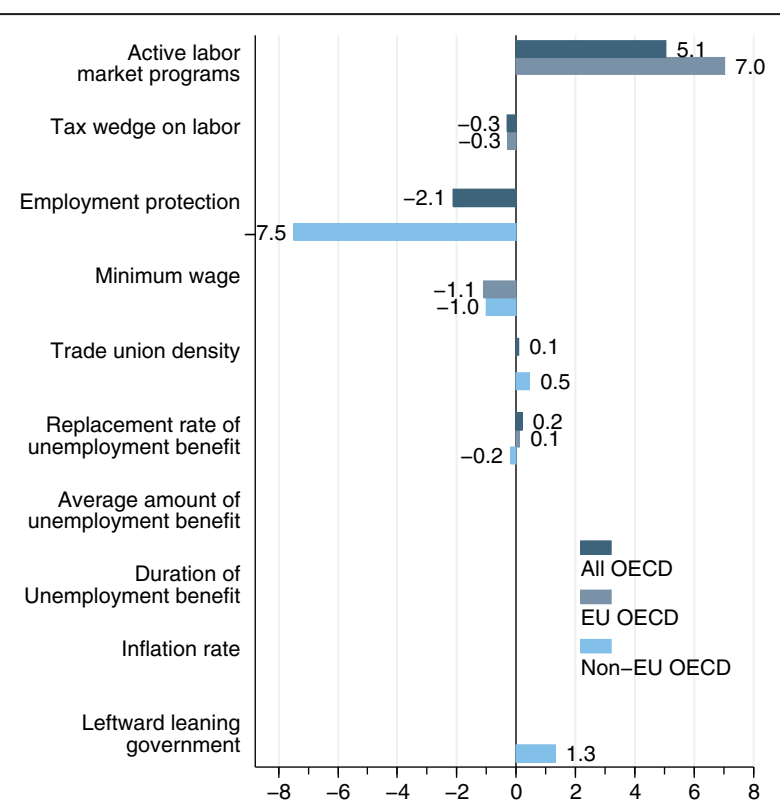

Figure 13 In Europe, active labor programs are associated with higher participation rates.

(percentage-point change in the working-age population working or searching for a job: estimated impact of a unit change in statistically significant explanatory variables). Note: Only coefficients significant at the 1 percent and 5 percent. levels are shown in the figure. Source: Fialová (2011). 


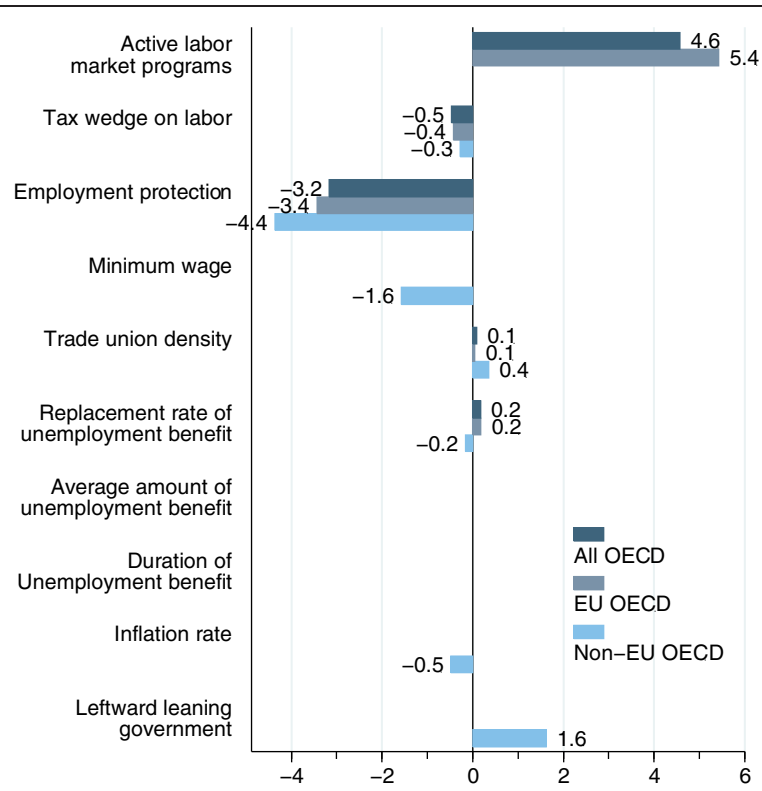

Figure 14 Rigid employment protection legislation is associated with lower employment rates.

(percentage employment rate: estimated impact of a unit change in statistically significant explanatory variables). Note: Only coefficients significant at the 1 percent and 5 percent levels are shown in the figure. Source: Fialová (2011).

higher labor taxation is negatively correlated with labor force participation-with the exception of the new member states-and positively correlated with unemployment rates, though the latter result is less robust. High labor taxation, associated with long-term unemployment, appears to be a major problem in Europe. Overall, the strictness of EPL and high labor taxes lower the employment rate.

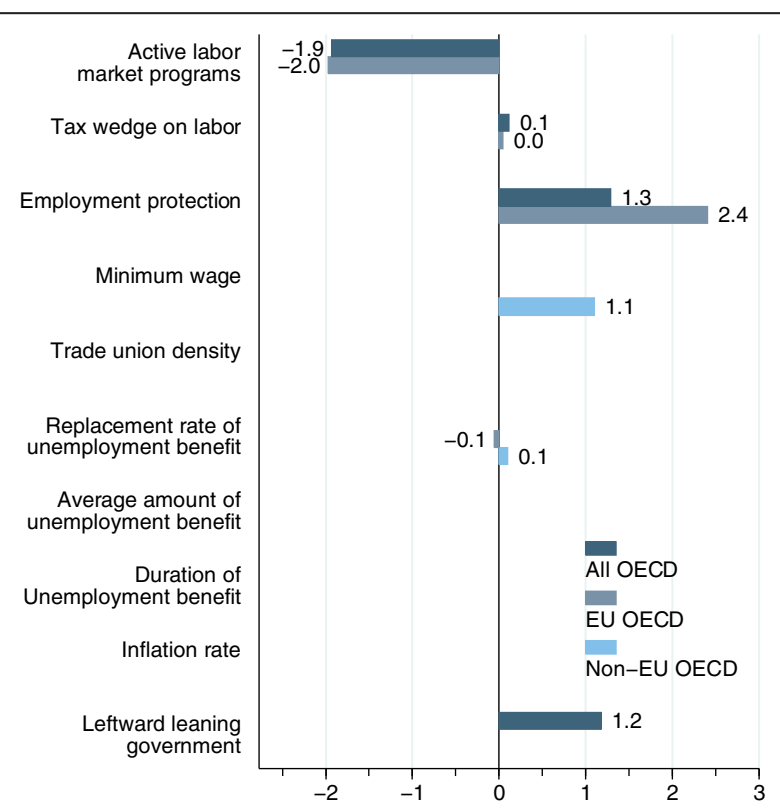

Figure 15 Rigid laws and high taxes are associated with higher unemployment rates. (percentage-point change in unemployment: estimated impact of a unit change in statistically significant explanatory variables). Note: Only coefficients significant at the 1 percent and 5 percent levels are shown. Source: Fialová (2011). 
Minimum wages are also negatively correlated with participation rates. This appears counterintuitive: the prospect of a higher wage should entice people into the market, not keep them out. But workers priced out of jobs as a result of minimum wages might be discouraged from further participating in the labor market-especially younger people and women. The minimum wage is also associated with higher unemployment rates-especially long-term unemployment rates-and lower employment rates.

Unionization is positively associated with participation in the labor market and employment rates, and seems to reduce long-term unemployment (in the European Union). Spending on active labor market programs is associated with higher rates of participation, lower unemployment rates, and higher employment rates. The relationship between the generosity of passive labor market programs and labor market outcomes appears more complex: while generosity tends to increase participation in Europe, it appears to have the opposite effect in non-European OECD countries. The generosity of unemployment benefits is also associated with lower unemployment and higher employment in Europe ${ }^{14}$.

When it comes to untaxed and unregulated work in the "shadow economy," Packard et al. (2012) found that when taking a country's development into account, EPL is associated with larger shares of shadow economy in GDP and greater labor informality. In the southern members of the European Union, where EPL is the most restrictive, all but the highest educated new entrants to the labor market are restricted to part-time and informal work.

The need to keep EPL sensible is at the core of Denmark's "flexicurity" model, which shifts protection away from jobs to the incomes of people who lose employment with efforts to get them back to work through training, job-search assistance, and help with starting businesses. These "active" intervention measures seem to improve performance and lower informal employment in OECD-member countries and Northern and Western EU member countries. Active programs also lower informal self-employment (Packard et al. 2012).

Germany has been getting attention for its attempts to liberalize a section of its labor market and to motivate people with strong incentives to remain idle (Zimmermann 2006; Goethe Institut 2007; and Grabka and Goebel 2011). Although Germany's approach may be all that can realistically be achieved given the controversial nature of labor market reform, it has raised questions of the sustainability and welfare of what could be a working "underclass" in jobs with less protection and even lower wages.

Germany experienced high unemployment rates of almost 10 percent between 1993 and 2004. By contrast, U.S. unemployment was about 5 percent. By 2004, almost 4.5 million Germans were unemployed according to the Federal Labor Agency. Less-skilled and older workers had higher unemployment rates; vocational school graduates and high school dropouts had unemployment rates of about 18 percent. In February 2002, the so-called Hartz commission suggested ways to modernize the labor market: improve employment services and active labor market programs, reform unemployment and social assistance benefit programs, and foster employment by deregulating the labor market.

The reforms were implemented between 2003 and 2005. They modernized public employment services and social welfare centers, modified existing active labor programs, and introduced new active labor programs. The reforms changed the institutional and legal framework for the rights and responsibilities of the unemployed and the beneficiaries 
of social assistance. Employment protection was reduced for parts of the labor market. Public employment services and social welfare centers adopted results-based accountability and outsourced services through competition between public and private providers. Employment offices were (partly) merged with social welfare units and converted into centers that provided job search assistance, social services, and benefit payments. Unemployment and social benefit levels and duration were reduced. Eligibility for subsistence allowances were changed according to a person's ability to work rather than previous history of contributions. Benefits were cut if recipients did not meet their responsibilities. Wage subsidies and start-up grants were provided to entrepreneurs. Jobs with reduced social security contributions were introduced ("midi-jobs"), and the regulations for jobs exempt from such contributions were reformed ("mini-jobs"). The objective was to lower the cost of hiring low skilled workers.

Between January and October 2006, the number of claimants in jobs requiring social insurance contributions rose 47 percent. The number of claimants working part-time grew 30 percent, and the number in marginal employment rose 14 percent. Workers who had survived on low wages without income support could now supplement their incomes with benefits. The reform of temporary work regulations increased employment in fixedterm jobs after the reform. But evaluations have found limited impact on mini-jobs.

The Hartz reforms helped reduce unemployment. Despite the crisis, Germany's unemployment rate today is about 7.5 percent, lower than the U.S. rate of more than 9.5 percent. Several authors have found that the reforms have significantly contributed to the resilience of the German labor market during the Great recession (Caliendo and Hogenacker 2012; Rinne and Zimmermann 2012). Many of the newly introduced parttime and temporary jobs have served as a bridge to regular jobs. But the reforms might also have reduced the income of low-wage earners, which has declined 16-22 percent over the last decade. Net real monthly income of workers in mini-jobs declined from $€ 270$ in 2000 to $€ 211$ in 2010, while income of workers in midi-jobs declined from $€ 835$ to $€ 705$. This is mainly due to an increase in the number of people in temporary work and part-time jobs.

The reforms raise several questions. First, given the difficulty of comprehensive labor reforms, does a partial liberalization targeted at some groups or sectors work? Second, do allowances in the labor code for more flexible forms of employment lead to a "two-tier" market and a legally sanctioned underclass? Third, do flexible and temporary forms of employment serve as a step toward advancement, or are people who enter through a midi- or mini-job experience scarred in ways that limit their future options? Germany's experience appears to be promising, but these doubts will be raised in countries that try to adopt strategies similar to the one proposed by the Hartz Commission.

\section{Labor mobility-a freedom forgone}

There are many reasons why labor mobility matters for productivity and growth. A country with a more mobile labor force uses available resources more effectively and is more likely to better match its human capital to other factors-both those that are more fluid such as capital, and those that do not move at all such as land. Recent work indicates that labor mobility is critical for social cohesion and the improvement of welfare in lagging regions ${ }^{15}$. When people move, they create links between places where economic activity is densely concentrated and those where it is not. These links become channels for 
resources that flow back to peoples' places of origin in the form of knowhow and remittances, that sustain the welfare of family members left behind and lead to investments in locally appropriate enterprises. Through these channels, increased labor mobility also contributes to economic convergence within countries, between leading and lagging regions, but also between countries, helping the new member states to achieve the living standards of the older member states. A mobile labor force can better adjust to shocks, and recover more quickly. Given its demographic outlook and the decline in the working-age population, increased labor mobility will be needed in Europe. And there is a lot of room for it.

\subsection{Europeans are less mobile}

The European Union is the most integrated region in the world, and accordingly, migration between EU countries is higher than in other world regions. Europe's aspiration, however, is more ambitious: a fully integrated labor market with no borders. Against this yardstick, Europe still falls short. By most measures, these differences are particularly great between the European Union and the United States (Eurofound 2007a,b,c, using Eurobarometer data 2005; Figure 16). In the former EU15, prior to enlargement in 2004 and 2007, only about 1 percent of the working-age population changed its country of residence in a given year. By contrast, until recently about 3 percent of the working-age population in the United States moved to a different state in a given year. In Australia, this figure is 2 percent; in Canada, slightly less than 2 percent. Even in Russia, with its history of outright restrictions on peoples' movement, mobility is 1.7 percent.

With a common language and fewer institutional differences, people in Australia, Canada, and the United States can move with greater ease than Europeans. Measures of movement between territories (at the Nomenclature of Territorial Units for Statistics 2 level) within EU countries change the picture considerably: about 21 percent of the EU population has lived in a territory or country other than where they were born. But even by this measure, labor mobility is still below that of the United States, where 32 percent of the population lives outside the state they were born $\mathrm{in}^{16}$. About 2 percent of the EU labor force was born in a member state different than their current state of residence; approximately 4 percent of the EU population has lived in another EU country at some point in their life; and 3 percent has lived in a country outside the European Union (Eurofound 2007a,b,c).

Internal mobility is difficult to compare across countries because its measurement depends on the size of the measurement unit. If the measurement unit is small-for example, the municipality - the corresponding internal migration rate will be high, because many more people move across municipalities than between provinces. Plotting the average size

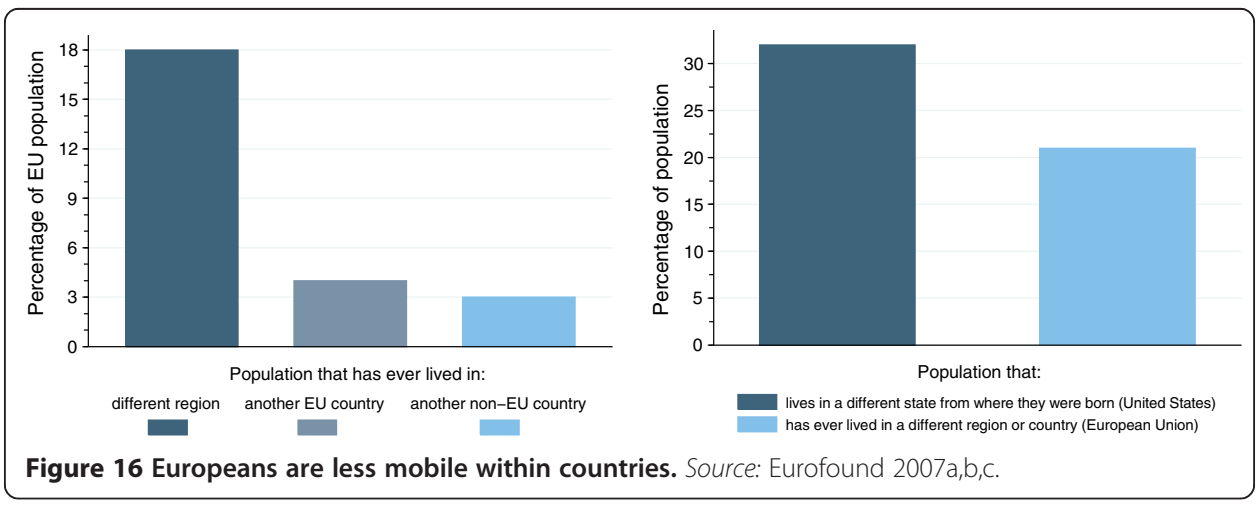


of the unit of measurement (like a region or district) against the corresponding internal migration rate controls for the size of administrative units. The exercise reveals that many European countries, especially the transition economies, have low labor mobility (World Bank 2012).

But lower labor mobility within a single market could reflect the smaller size of countries and shorter distances between centers of economic activity. Why move when you can commute? In a 2008 report on labor mobility in Europe, the Institute for the Study of Labor adopted a broad definition of geographic mobility that included not only changes of residency within countries and across borders but also cross-border and regional commuting (Bonin et al. 2008, using the European Labor Force Survey). The report showed that between 2000 and 2005, workers' mobility within the European Union was barely 1 percent each year and that the movement of people in Europe was lower than mobility across Australian ( 2 percent) and U.S. states (3 percent).

The report also showed that in the EU15, the share of the active working-age, foreignborn population from an EU27 country increased during the previous decade. Spain had the largest increase, followed by Greece, Denmark, Portugal, Sweden, Ireland, the United Kingdom, and Austria. Among the newer member states, those with the highest initial share of foreign-born people (Latvia and Estonia) showed a decline over time. In most EU15 countries, foreign nationals from another EU15 country comprise only a small share of foreign nationals. An exception can be found in the United Kingdom: The largest nonnative resident minority group in London is from France.

These statistics present a paradox. The movement of people within the European Union is one of the Four Freedoms, and probably the one that comes most immediately to the average European's mind when asked why the European Union is important. Yet, the Eurobarometer survey in 2005 showed that lifetime mobility of European citizens across EU borders is rather limited (Table 1). In most EU countries, less than 5 percent of the population have ever moved from one EU country to another.

This may be changing. The same survey showed that mobile Europeans are younger and have higher levels of education than those who have no intention of moving. Students in Europe are among the most mobile, enthusiastically taking advantage of such crossborder education programs as Erasmus. For many, these programs lead to longer term resettlement for employment. Parey and Waldinger (2011) find that studying abroad with ERASMUS increases an individual's probability of working in a foreign country by about 15 percentage points. Indeed, recent statistics show an increase in mobility. In 2008, about 2.3 percent of EU citizens (11.3 million people) resided in a member state other than their citizen state, according to the European Commission ${ }^{17}$. That number has grown more than 40 percent since 2001.

A lack of movement is often blamed for high unemployment rates in areas that lag and for labor shortages that drive up wages in places that lead. This negative correlation between mobility and unemployment is apparent in data from selected OECD countries for 1980 to 1995 (Hassler et al. 2001; Figure 17). Labor markets can respond differently to shocks, often resulting in differences in the impact on jobs across areas. Adjustment to regional shocks in Europe has been achieved more through unemployment rates and changes in labor force participation (people stop looking for work if a region goes into economic decay) and less through mobility of labor ${ }^{18}$. By contrast, in the United States, labor mobility leads to greater agility in 
Table 1 Internationally, the Irish are the most mobile Europeans in the single market

\begin{tabular}{|c|c|c|c|}
\hline & Local move & Move in country & Move inside the European Union \\
\hline Ireland & 44.5 & 18.8 & 14.5 \\
\hline Luxembourg & 53.8 & 19.4 & 13.2 \\
\hline Cyprus & 47.8 & 17.2 & 8.1 \\
\hline Denmark & 62.6 & 36.2 & 7.5 \\
\hline Sweden & 65.9 & 41.8 & 7.1 \\
\hline United Kingdom ${ }^{a}$ & 52.3 & 23.7 & 6.6 \\
\hline Finland & 64.5 & 34.7 & 5.1 \\
\hline Germany & 59.4 & 18.1 & 4.9 \\
\hline Belgium & 59.6 & 13.0 & 4.5 \\
\hline Spain & 46.6 & 9.9 & 4.5 \\
\hline Greece & 34.7 & 16.4 & 4.4 \\
\hline Netherlands & 55.0 & 21.6 & 4.4 \\
\hline Portugal & 41.7 & 8.6 & 4.2 \\
\hline Austria & 54.1 & 9.4 & 3.4 \\
\hline Malta & 27.6 & 6.2 & 2.7 \\
\hline France & 58.2 & 28.8 & 2.6 \\
\hline Latvia & 44.2 & 22.5 & 2.0 \\
\hline Czech Republic & 41.9 & 8.2 & 1.6 \\
\hline Italy & 43.8 & 7.9 & 1.6 \\
\hline Slovenia & 38.2 & 9.6 & 1.6 \\
\hline Slovak Republic & 34.2 & 5.8 & 1.4 \\
\hline Estonia & 50.5 & 23.4 & 1.1 \\
\hline Poland & 40.6 & 7.1 & 1.0 \\
\hline Hungary & 47.5 & 9.9 & 0.7 \\
\hline Latvia & 57.4 & 7.4 & 0.7 \\
\hline
\end{tabular}

a. Includes Northern Ireland.

Note: Weighted averages. Multiple answers allowed.

Source: Bonin et al. 2008.

(lifetime mobility, percentage of population, by type of mobility).
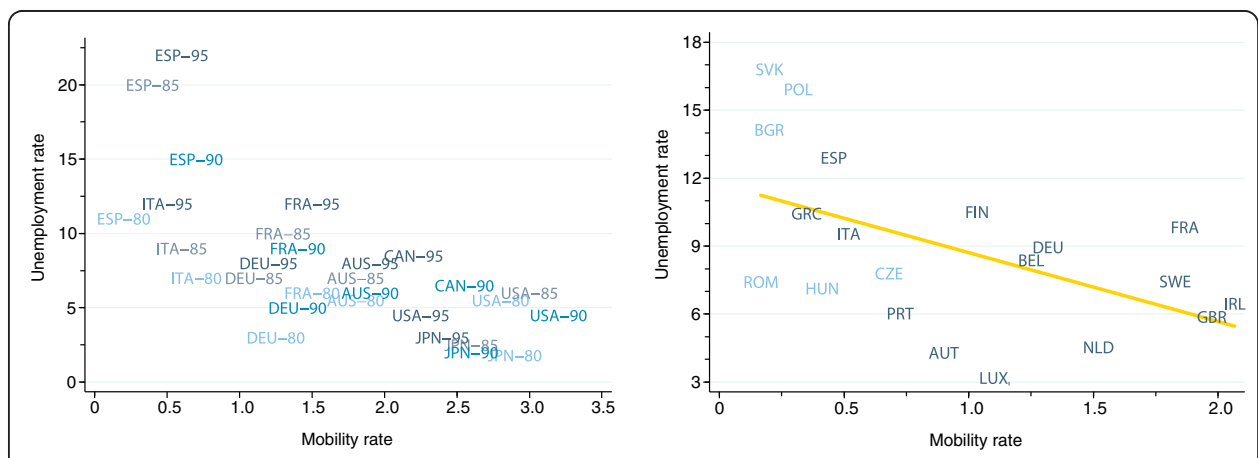

Figure 17 Low labor mobility can keep unemployment high. (labor mobility and unemployment rates in the nine largest OECD countries, 1980-95). Source: Hassler et al. 2001. (labor mobility and unemployment rates in EU member states, 1995-2006). Source: World Bank staff, based on Eurostat data. 
responding to differences in wages and job opportunities across states, reducing disparities in unemployment rates and real wages.

But does a mobile labor force really make much of a difference for a country's economic prospects? Policymakers are aware of statistics showing the relative immobility of Europeans and are eager to know what they can do about it. The phased withdrawal of restrictions on the movement of people from the newest member states of the European Union has been an obvious obstacle that will disappear in time. Yet people from the newer member states still face explicit barriers to mobility within the European Union ${ }^{19}$. Lessons from how different EU15 members have managed this aspect of enlargement are still being absorbed, but evidence from movements since 2004 and in reaction to the crisis indicate that the member states that embraced newcomers from the newest member countries benefited. Kahanec and Zimmermann (2009), for example, find substantial long-term positive impacts on GDP, GDP per capita, productivity and wages in the EU15 countries from post-enlargement immigration.

Looking beyond adjustment to shocks and recovery from the recession, growing literature provides evidence that internal labor mobility tends to have positive effects on countries' productivity and growth. For example, without mobile labor, the growth rate of the United States would likely have been only half of what it actually has been (World Bank 2009). In Canada, the movement of people across provinces contributed to economic growth (Sharpe et al. 2007). Due to the high volume of movement from low-productivity eastern provinces to high-productivity western provinces, Canada benefited from a huge boost to economic growth in 2006.

Further, countries with higher labor mobility have better performing labor markets and higher rates of employment. For instance, the three European countries that have reached the Lisbon employment targets-the Netherlands, Sweden, and the United Kingdom-all have labor mobility rates in the top quartile (Figure 18). Conversely, countries with the highest dispersion in employment rates across their territories (Italy, Spain, Hungary, and the Slovak Republic) have mobility rates below the European average ${ }^{20}$.

Researchers have been trying to identify the impediments to mobility in economic areas where labor is legally free to move. Language and cultural barriers obviously play a role (OECD 2007). But putting language aside, even with a legal right to work in every member

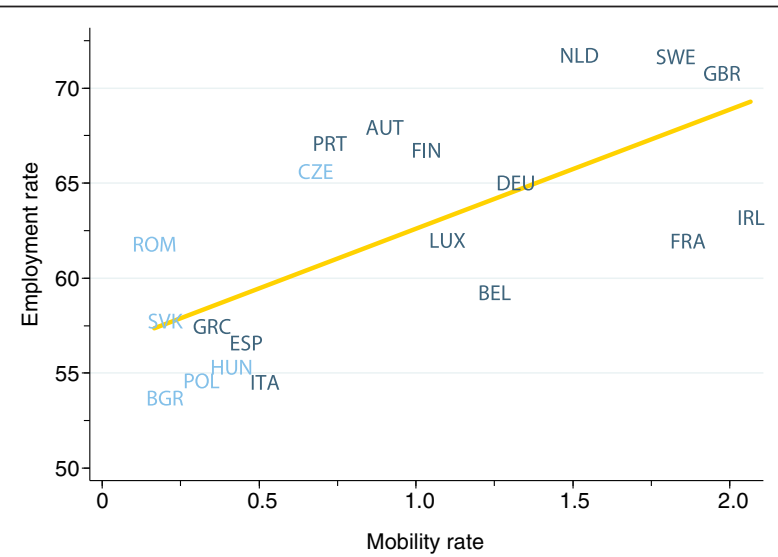

Figure 18 Greater labor mobility is associated with higher rates of employment in Europe.

(correlation between labor mobility rate [average 1996-2006, horizontal axis] and employment rate [average 1996-2006, vertical axis], selected European countries: coefficient 0.677). Note: Labor mobility is the share of the population that moved from one region (Nomenclature of Units for Territorial Statistics 2) to another within a given year. Source: World Bank estimates, using Eurostat data. 
state, EU citizens face implicit but powerful deterrents created by differences in rules that determine social insurance coverage, the accrual of occupational pension rights, entitlements to social housing and other forms of assistance, and the recognition of their professional qualifications and previous work experience. Perhaps reflecting the current tough times, as in Europe, local chambers of commerce and professional guilds of U.S. trade associations are starting to erect barriers-even to people offering their services online-in order to restrict movement and thus competition. This strict "rule of license" is an obstacle to movement and faster labor market adjustment. These impediments may be more serious for prime-aged workers than for the young or the retired. As the median age of Europeans increases from 40 years today to nearly 50 by 2050, the mobility imperative will become more pressing.

\subsection{What keeps Europeans at home}

Among the strongest deterrents to greater mobility in Europe are those created by failures in housing markets (Figure 19). In many European countries, housing is a good that is still exchanged informally on unregulated or poorly regulated markets (Janiak and Wasmer 2008). Rental markets are shallow, rent is expensive, and supply is limited by zoning restrictions. These problems constrain people's mobility at both their origin and destination: moving can be a costly prospect, made more so by difficulties selling or renting one's house. Bottlenecks in the housing market are a serious impediment to mobility. Homeowners in Europe are more sluggish to move in response to changing labor market conditions than people who rent their homes (Hughes and McCormick 1985, 1987; Henley 1998; Gardner et al. 2001). The relatively high unemployment rates in some European countries can be explained in part by a large portion of people who are owner-occupiers (Haavio and Kauppi 2003). The constraints to labor mobility created by failures in the housing market have been documented elsewhere (Mansoor and Quillin 2006) and create powerful deterrents to movement even in countries on the European Union's doorstep.

Another likely culprit preventing Europeans from moving is the relative rigidity of wages and generous pay-out periods of unemployment insurance plans. Wage regulation leads to an earnings compression that can mute the signals that the labor market sends from one part of a country to another. If wages are not sufficiently flexible, they can fail to provide incentives for capital to flow into economically lagging regions or

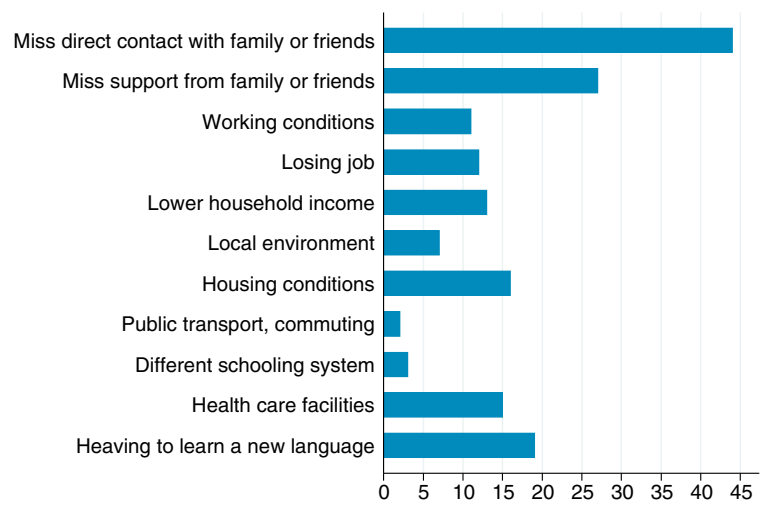

Figure 19 Language, housing, and health care are the main impediments to mobility. (factors that deter people from moving to another EU country [percent]). Note: Figures are for respondents from the EU25 who do not intend to move. Source: Karppinen et al. 2006. 
for workers to move to economically booming regions. Generous unemployment insurance plans that provide support over long periods can act as a disincentive for workers with industry-specific or place-specific skills to retrain and move. In principle, the relationship could also be reverse in the sense that more generous unemployment benefits can give job seekers the resources and time to look for better matching job offers in other regions. Yet, as Hassler et al. (2001) show, on average there seems to be a negative relationship between mobility rates and unemployment insurance: high-mobility countries are characterized by low unemployment insurance benefits, while lowmobility countries have the most generous unemployment insurance plans.

Higher structural unemployment in many European countries also deters the movement of labor. Although differences in unemployment rates between the lagging and leading parts of a country should encourage movement, a high overall national unemployment rate will discourage people from taking the risk. Unemployed workers will probably not want to pay the cost of moving to more dynamic parts of their country if they would still face the high likelihood of not finding a job ${ }^{21}$.

The lack of portable social benefits-such as pensions, health care, and social assistance-might also constrain the mobility of labor between EU countries. EU legislation grants portability of such benefits at a level not found in any other region of the world. In principle, the most important benefits (for example, public pension and health benefits) are fully portable within the European Union and, to some extent, with countries outside the European Union. Nevertheless, important challenges remain ${ }^{22}$. First, the administration of portability can be burdensome for intra-EU migrants. For example, old-age pensions are not paid as a single benefit, but by each pension insurance fund separately. The determination of separate pensions, taking into account contribution periods from different member states, is complex and opaque. Second, legislation on portability does not apply to occupational benefits, so moving might lead to considerable losses. Third, social assistance benefits are excluded from portability; the lack of a Europe-wide social safety net could also act as a barrier to intra-EU mobility.

Finally, some EU policies may inadvertently be keeping Europeans immobile. The free flow of trade in goods and foreign direct investment across the single market might reduce the need for labor to move. Trade flows react more elastically than people, and capital is far more mobile. Trade in goods-particularly intermediate goods-along with capital transfers could make the movement of labor to other economic areas less important. This is a "good reason" for lower labor mobility in Europe, especially in the European Union. But other policies may not be so benign. European agriculture and cohesion policies and investments from regional and structural funds could be creating disincentives for mobility. Regional development policy instruments pour investment into economically lagging areas, sometimes with the stated objective of fostering job creation to retain young and qualified workers. Although the track record of these policies is mixed at best, to the extent that they deter movement of people at the margin, they obviate the need for European workers to move to where persistent vacancies arise.

\section{Conclusions}

If current trends persist, members of the European Union, the EFTA countries, the candidate countries, and the eastern European partnership countries will lose almost 50 million 
workers between now and 2060. Today, the European labor force-the employed and active job seekers-consists of 323 million people; in 50 years, it will be down to 273 million, a decrease of 15.3 percent. Over the next 20 years, the labor force will lose 15 million workers. The largest reduction will happen during the 2030s, when the European labor force is expected to fall an additional 14 million people. The fall will be especially severe for the European Union and EFTA countries. Their labor force will decrease by almost 40 million people (18 percent) over the next 50 years. The other eastern European countries will not fare much better, with an equally steep decline of 16 percent.

These trends should not be allowed to persist. Many Europeans-especially women, youth, elderly, and some minorities-do not work at all, and they should. Many Europeans retire too early, and they should work longer. Some unemployed Europeans do not look hard enough for work, and they should be encouraged to look harder. Only with radical policy and behavioral changes can Europe counter the shrinking labor force. Yet, even under such optimistic conditions, Europe will not be able to prevent its labor force from aging. If participation rates in all countries were to converge to those in northern Europe, or the retirement age were to increase by 10 years across the board, the European labor force would actually increase by 2060. If female labor force participation were to converge to that of men, the labor force would still decrease, but only by 5 percent, as opposed to 15 percent in the baseline scenario. None of these scenarios counteracts, however, the loss of young workers due to continually decreasing younger-age cohorts. Thus, as argued in Golden Growth, increased migration will also have to be part of the solution. With revamped immigration policies that combine the altruism of humanitarian policies with the self-interest of an economic approach, Europe can attract bright Africans, Americans, and Asians.

Revisiting the questions posed at the beginning of the paper may be useful.

Are employment and social protection practices reducing participation? In most countries, they do, and reforming these policies can stem some if not most of the projected decline of the European labor force, especially by increasing participation rates of older workers and women. Yet, in addition to immigration, increased investments in human capital are also necessary to not only have more, but also more productive workers. Interventions should focus on overcoming failures in information and quality assurance that lead many people to make suboptimal skills investments (too few engineers, technicians, and competent managers). Countries in emerging Europe have to reorganize their school networks in the face of shrinking student cohorts, and pay more attention to developing critical cognitive and non-cognitive skills during preschool and basic education.

Are employment and social protection practices inhibiting efficiency? Yes, by creating influential insiders with well-protected jobs at the cost of marginalizing others. The reforms will have to reduce job security while modernizing the systems for providing income security. In wealthier countries, reduced employment protection can be combined with relatively generous unemployment benefits and social assistance. Governments capable of administering programs that supplement employment protection laws with well-designed income support and job search assistance should institute them. But to work well, this "flexicurity" requires high labor force participation rates that are many years away for many in Europe, as well as an institutional maturity and fiscal and administrative resources that are out of reach for most. Especially in the east and south but perhaps also in other countries, there may be no alternative but to reconsider the extent of employment protection and the generosity of social protection. But all countries should synchronize social 
insurance for the unemployed with social assistance for the unlucky in order to align incentives for work, as Germany did between 2003 and 2005.

Is Europe taking advantage of the potential for greater labor mobility? Not fully. Undoubtedly, the European Union is the most integrated region in the world, and migration between EU countries is higher than in other world regions. Europe's aspiration is, however, more ambitious: the aim is a fully integrated labor market with no borders. Against this yardstick, Europe still falls short. Significant challenges to improving labor mobility, even within European countries, remain. Mobility does come with social costsmissing the support of family and friends-that governments cannot easily reduce. But the costs related to education, housing, and health care can and should be reduced. These are some of the features that make the United States the most mobile economy in the world, and Europe can learn without losing its uniqueness.

Looking back at the last decade and a half, emerging Europe may have done better than advanced Europe in taking advantage of expanding opportunities for trade, finance, and enterprise. Looking ahead, the prospects are bleaker. Demographic shifts threaten Central and Eastern Europe just as much as most countries in Western Europe. The exception is Southern Europe, which has not done well in recent years and is projected to shrink and age over the next decade. Greece, Italy, Portugal, and Spain illustrate most starkly how work is simultaneously the weakest part of the European economic model and one of its most attractive attributes. Changing how the labor market is regulated and replenished will be difficult for politicians, but it is nonetheless urgent. Nor is it hopeless: countries such as Denmark, Germany, Ireland, and Sweden have shown that the European work model's characteristics can be changed while keeping its character distinctly European.

This paper is perhaps best concluded with a simple (but uncomfortable) answer to the principal question it addresses: Can Europe attain full employment? The answer is yes, but not until the continent is willing to make radical changes in its approach to work. A central aspect is that most countries in Europe give disproportionate power to those with protected jobs - the "insiders" - through employment protection legislation. This approach would have become difficult to sustain even without the onset of rapid aging. With this shift, it is already unsustainable. Countries such as Denmark and Germany-but also other Nordic countries, Austria, the Netherlands, and Switzerland-which have kept unemployment low and labor force participation high during the last decade, have done so in some measure by reducing this protection. In effect, they have made jobs contestable. Now others must do the same.

\section{Endnotes}

${ }^{1}$ In the chapter on labor in Gill and Raiser (2012), on which this paper is based, we discuss a wider range of constraints on employment outcomes, from regulation to immigration. For the sake of brevity, we have reduced the scope of discussion in this paper to just 'within market' factors. Readers are referred to Gill and Raiser (2012) for the full treatment including of immigration policies.

${ }^{2}$ This projection assumes that overall immigration and participation rates by sex and age group remain at current levels.

${ }^{3}$ For a more detailed discussion on incentivizing formal work, see World Bank (2011a). 
${ }^{4}$ See Hanushek and Woessmann (2008) for a literature review of the empirical relationship between economic growth and school attainment.

${ }^{5}$ See Carneiro and Heckman (2002) for U.S evidence, Brunello and Schlotter (2011) for Europe, and World Bank (2011a) for summary evidence in middle-income countries.

${ }^{6}$ See, for example, Bowles and Gintis (1998) for evidence of employer surveys from the United Kingdom and the United States, Blom and Saeki (2011) for a study for India, and World Bank (2011b) for evidence from Latin America.

${ }^{7}$ For an extensive treatment of the impact of labor unions on labor-market outcomes in Europe, see Alesina et al. (2005).

${ }^{8}$ Following Fialová and Schneider (2009, 2011), we use two-stage least squares regression estimation with instrumental variables on pooled data. Standard panel estimation procedures (random or fixed effects estimation) were not employed for insufficient explanatory power of these models and/or too few data. Data were mainly from OECD with some supplements from the Institute for the Study of Labor, International Labour Organization, and European Bank for Reconstruction and Development.

${ }^{9}$ The findings correspond with previous empirical studies using similar techniques by Cazes and Nesporova (2003) and Nickell (1997). With respect to long-term unemployment, employment protection legislation was generally found to be insignificant across country samples. Active labor market policy spending was also insignificant.

${ }^{10}$ For detailed descriptive statistics of independent variables used in the regressions, see Fialová and Schneider $(2009,2011)$ and Fialová (2011). Over the whole sample of countries, the average for active labor market policy expenditure was 10.1 percent of GDP, the average implicit tax rate on labor was 35.1 percent, the average EPL index was 2.3, the average minimum wage as a share of average earnings was 40.3 percent, and average trade union density was 35.6 percent.

${ }^{11}$ The data are from the OECD, for 2001-07. The sample covers Australia, Austria, Belgium, Canada, the Czech Republic, Denmark, Finland, France, Germany, Greece, Hungary, Ireland, Italy, Japan, the Republic of Korea, the Netherlands, Norway, New Zealand, Poland, Portugal, Spain, Sweden, the United Kingdom, and the United States. Of them, 17 are classified as EU OECD and 7 as non-EU OECD.

${ }^{12}$ The sample covers Austria, Belgium, the Czech Republic, Denmark, Finland, France, Germany, Greece, Hungary, Ireland, Italy, the Netherlands, Norway, Poland, Portugal, Spain, Sweden, and the United Kingdom. Of them, 15 are classified as old European Union and 3 as new member states of the European Union.

${ }^{13}$ Data are from the Institute for the Study of Labor database, for 1999, 2003, and 2007. The sample covers Albania, Bulgaria, Croatia, the Czech Republic, Estonia, Hungary, the Kyrgyz Republic, Latvia, Moldova, Macedonia, Poland, Romania, the Slovak Republic, Slovenia, and Ukraine. Of them, 9 are classified as new member states of the European Union and 6 as European neighborhood.

${ }^{14}$ The generosity of unemployment benefits seems to have the reverse effect in nonEuropean OECD countries.

${ }^{15}$ Bertola and Ichino (1995) argue that the persistence of unemployment in Europe in the 1980s and 1990s was caused by a lack of labor mobility and people remaining in lagging areas.

${ }^{16}$ However, Eurofound $(2007 \mathrm{a}, \mathrm{b}, \mathrm{c})$ presents data that indicate a decrease in interstate mobility in the United States over 2000-05. 
${ }^{17}$ See European Commission (2010b). In 2008, 37 percent (11.3 million people) of nonnationals in EU27 countries were citizens of another member state. The number of nonnationals in EU27 has increased 42 percent since 2001 (for further details, see Eurostat Statistics in focus 94/2009).

${ }^{18}$ Tatsiramos (2007) makes reference to important work by Decressin and Fatas (1995) and Jimeno and Bentolila (1998) about European trends. For the United States, Tatsiramos quotes Blanchard and Katz (1992).

${ }^{19}$ Restrictions on the freedom to work can be maintained for up to seven years after the entry of new member states into the European Union. The last restrictions were lifted on workers from the EU8 countries in May 2011. Restrictions will be lifted on workers from Bulgaria and Romania in December 2013.

${ }^{20}$ Using Nomenclature of Units for Territorial Statistics 2 data.

${ }^{21}$ See, for instance, Bentolila (1997) for Spain; Pissarides and Wadsworth (1989) for the United Kingdom; and Fidrmuc (2004) for transition economies.

${ }^{22}$ For a detailed discussion on conceptual issues regarding portability of social benefits, see Holzmann and Koettl (2011).

Competing interest

The IZA Journal of European Labor Studies is committed to the IZA Guiding Principles of Research Integrity. The authors declare that they have observed these principles.

\begin{abstract}
Authors' information
Indermit Gill is the Director for Development Policy at the Development Economics and Chief Economist (DEC) department of the World Bank. Prior to taking this position, he was the Chief Economist of the World Bank's Europe and Central Asia Regional Office, and before that he was the Director of the World Development Report 2009 "Reshaping Economic Geography." He has an M.A. in Economics from the Delhi School of Economics, and a Ph.D. in Economics from the University of Chicago.

Johannes Koettl is Senior Economist in the Human Development Economics group of the World Bank's Europe and Central Asia Regional Office and a Research Fellow at IZA. He has been working on issues related to labor markets, migration, health, and social protection at the World Bank since 2004. Previously he completed an M.A. in International Relations at Johns Hopkins University's School of Advanced International Studies and a Ph.D. in Economics at the University of Vienna and the Institute for Advanced Studies (IHS) Vienna. His current work focuses - among other topics on labor markets in transition countries, aging, informal employment, and migration.

Truman Packard is Lead Economist for Human Development for the Pacific, part of the World Bank's East Asia and the Pacific Regional Office. Prior to that, he was Lead Economist in the Human Development Economics group for the World Bank's Europe and Central Asia Regional Office. Trained as a labor economist, his work has focused primarily on the impact of social insurance on household labor supply decisions, saving behavior and risk management. Since 1997 Truman has worked for World Bank country and regional programs in Latin America and the Caribbean, East Asia and the Pacific, and in Central and Eastern Europe. He served as co-deputy director for the World Development Report 2009 "Reshaping Economic Geography" leading the analysis of labor migration. Truman holds a Ph.D. in Economics from the University of Oxford.
\end{abstract}

\title{
Acknowledgements
}

This paper is based on the chapter on labor in Gill and Raiser, Golden Growth: Restoring the Lustre of the European Economic Model, published by the World Bank in 2012. The authors are indebted to Indhira Santos, Lazar Sestovic, Kamila Fialova who contributed substantial input to the labor chapter in particular, as well as to many others who contributed to that report.

Responsible editor: Martin Kahanec.

\section{Author details}

${ }^{1}$ The World Bank, 1818 H ST NW, Washington, DC 20433, USA. ${ }^{2}$ The World Bank and IZA, 1818 H ST NW, Washington, DC 20433, USA.

Received: 1 October 2013 Accepted: 22 November 2013

Published: 16 Dec 2013

\section{References}

Alesina A, Glaeser E, Sacerdote B (2005) Work and Leisure in the United States and Europe: Why so Different? In: Gertler M, Rogoff K (eds) NBER Macroeconomics Annual 2005. National Bureau of Economic Research, Cambridge, MA Bentolila S (1997) Sticky Labor in Spanish Regions. European Economic Review 41(3-5):591-598 Bentolila S, Dolado J, Jimeno J (2008) Two-tier Employment Protection Reforms: The Spanish Experience. CESifo DICE Report 6(4):49-56 
Bentolila S, Dolado J, Jimeno J (2012) Reforming an insider-outsider labor market: the Spanish experience. IZA Journal of European Labor Studies 1:4

Bertola G, Ichino A (1995) Wage Inequality and Unemployment: United States vs. Europe. In: Bernanke B, Rotemberg J (eds) NBER Macroeconomics Annual 1995, Volume 10. MIT Press, Cambridge, MA, pp 13-66

Blanchard O, Katz L (1992) Regional Evolutions. Brookings Papers on Economic Activity 1992(1):1-61

Blanchard O, Tirole J (2003) Protection de l'emploi et procédures de licenciement. CAE Report, http://www.cae-eco.fr/ IMG/pdf/06-2003-EN.pdf

Blom A, Saeki H (2011) Employability and Skill Set of Newly Graduated Engineers in India. In: Policy Research Working Paper 5640. World Bank, Washington, DC

Boeri T (2011) Institutional Reforms and Dualism in European Labour Markets. In: Ashenfelter O, Card D (eds) Handbook of Labor Economics Vol. 4b. Elsevier, Amsterdam

Boeri T, Garibaldi P (2007) Two-tier Reforms of Employment Protection Legislation: A Honeymoon Effect. Economic Journal 117:357-385

Bonin H, Eichhorst W, Florman C, Hansen MO, Skiöld L, Stuhler J, Tatsiramos K, Thomasen H, Zimmermann KF (2008) Geographic Mobility in the European Union: Optimizing its Economic and Social Benefits. In: Research Report 19, Institute for the Study of Labor, Bonn, Germany

Bover O, Gomez R (2004) Another Look at Unemployment Duration: Exit to a Permanent versus a Temporary Job. Investigaciones Economicas 28:285-314

Bowles S, Gintis H (1998) Does Schooling Raise Earnings by Making People Smarter? University of Massachusetts, Amherst, MA

Brunello G, Schlotter M (2011) Non Cognitive Skills and Personality Traits: Labour Market Relevance and their Development in Education \& Training Systems. In: Discussion Paper 5743. Institute for the Study of Labor, Bonn, Germany

Cahuc P, Kramarz F (2004) De la précarité à la mobilité: vers une Sécurité sociale professionnelle. In: Report for the Ministry of Economy, Finance and Industry and the Ministry of Employment. Labor and Social Cohesion, Paris, http://ces.univ-paris1.fr/membre/canry/Fichiers\%20Politiques\%20Sociales/Cahuc\%20Kramarz\%202004.pdf

Cahuc P, Postel-Vinay F (2002) Temporary Jobs, Employment Protection and Labor Market Performance. Labor Economics 9:63-91

Caliendo M, Hogenacker J (2012) The German labor market after the Great Recession: successful reforms and future challenges. IZA Journal of European Labor Studies 1:3

Card D, Kluve J, Weber A (2010) Active Labour Market Policy Evaluations: A Meta-Analysis. Economic Journal 120(548): F452-F477

Carneiro P, Heckman JJ (2002) The Evidence on Credit Constraints in Post-Secondary Schooling. In: Discussion Paper 518. Institute for the Study of Labor, Bonn, Germany

Cazes S, Nesporova A (2003) Labor Markets in Transition: Balancing Flexibility and Security in Central and Eastern Europe. International Labour Organization, Geneva

Davis S, Henrekson M (2004) Tax Effects on Work Activity, Industry Mix and Shadow Economy Size: Evidence from Rich Country Comparisons. In: Working Paper 10509. National Bureau for Economic Research, Cambridge, MA

Decressin J, Fatas A (1995) Regional Labor Market Dynamics in Europe. European Economic Review 39:1627-1655

Dolado J, Garcia-Serrano C, Jimeno J (2002) Drawing Lessons from the Boom of Temporary Jobs in Spain. Economic Journal 112:270-295

Eichhorst W, Marx P (2009) From the Dual Apprenticeship System to a Dual Labor Market? The German High-Skill Equilibrium and the Service Economy

Estevão M, Sá F (2008) The 35-hour workweek in France: Straightjacket or welfare improvement? Economic Policy 23 (55):417-463

European Commission (2010a) Communication: Europe 2020. A Strategy for Smart, Sustainable, and Inclusive Growth COM/2010/2020, European Commission, Brussels

European Commission (2010b) Communication: Reaffirming the Free Movement of Workers: Rights and Major Developments. In: COM/2010/0373. European Commission, Brussels

European Commission (2010c) Employment in Europe 2010. European Commission, Brussels

European Foundation for the Improvement of Living and Working Conditions (Eurofound) (2007a) Long-distance Mobility in Europe: Getting the Balance Right. Available at http://www.eurofound.europa.eu/publications/htmlfiles/ ef0636.htm

European Foundation for the Improvement of Living and Working Conditions (Eurofound) (2007b) Mobility in Europe - The Way Forward. Available at http://www.eurofound.europa.eu/publications/htmlfiles/ef0703.htmen/1/ef0703en.pdf

European Foundation for the Improvement of Living and Working Conditions (Eurofound) (2007c) Labour Mobility in a Transatlantic Perspective. Conference Report, Dublin, October 30-31. Available at http://www.eurofound.europa.eu/ publications/htmlfiles/ef0826.htm

Eurostat (2011) Eurostat online database. Available at http:/epp.eurostatec.europa.eu/portal/page/portal/eurostat/home/

Fialová K (2011) Labor Market Institutions and their Effect on Labor Market Performance in OECD and European Countries. World Bank, Washignton, DC

Fialová K, Schneider O (2009) Labor Market Institutions and their Effect on Labor Market Performance in the New EU Member Countries. Eastern European Economics 47(3):57-83

Fialová K, Schneider O (2011) Labor Institutions and their Impact on Shadow Economies in Europe". Background Paper for "In from the Shadow: Integrating Europe's Informal Labor. World Bank, Washington, DC

Fidrmuc J (2004) Migration and Regional Adjustment to Asymmetric Shocks in Transition Economies. Journal of Comparative Economics 32(2):230-247

García Pérez J, Osuna V (2011) The effects of introducing a single open-ended contract in the Spanish labour market, " Working Papers 11.07. Department of Economics, Universidad Pablo de Olavide

Garcia-Serrano C (1998) Worker Turnover and Job Reallocation: The Role of Fixed-Term Contracts. Oxford Economic Papers 50:709-725 
Gardner J, Pierre G, Oswald A (2001) Moving for Job Reasons. Department of Economics, University of Warwick, Coventry, Mimeo

Gill I, Raiser M (2012) Golden Growth: Restoring the Lustre of the European Economic Model. World Bank, Washington, DC

Goethe Institut (2007) Hartz IV—More Dependency on the State. Available at http://www.goethe.de/ges/soz/soz/ en2606706.htm

Grabka MM, Goebel J (2011) Entwicklung der Altersarmut in Deutschland. In: Paper 378, German Socio-Economic Panel. German Institute for Economic Research, Berlin

Guell M, Petrongolo B (2007) How Binding are Legal Limits? Transitions from Temporary to Permanent Work in Spain. Labour Economics 14:153-183

Haavio M, Kauppi H (2003) Housing Markets and Labor Mobility

Hanushek EA, Woessmann L (2008) The Role of Cognitive Skills in Economic Development. Journal of Economic Literature 46(3):607-668

Hassler J, Rodríguez Mora JV, Storesletten K, Zilibotti F (2001) A Positive Theory of Geographic Mobility and Social Insurance. International Economic Review 46:263-303

Hazans M (2011) What Explains Prevalence of Informal Employment in European Countries: The Role of Labor Institutions, Governance, Immigrants, and Growth. In: Background Paper for Packard, Koettl, and Montenegro. 2012. In from the Shadow: Integrating Europe's Informal Labor. Washington, DC, World Bank

Henley A (1998) Residential Mobility, Housing Equity and the Labour Market. The Economic Journal 108(447):414-427

Holmlund B (1998) Unemployment insurance in theory and practice. Scandinavian Journal of Economics 100:113-141

Holzmann R, Koettl J (2011) Portability of Pension, Health, and Other Social Benefits: Facts, Concepts, Issues. In: Discussion Paper 5715. Institute for the Study of Labor, Bonn, Germany

Hughes G, McCormick B (1985) Migration Intentions in the U.K.: Which Households Want to Migrate and Which Succeed? The Economic Journal 95(Supplement, Conference Papers):113-123

Hughes G, McCormick B (1987) Housing Markets, Unemployment and Labour Market Flexibility in the UK. European Economic Review 31(3):615-641

Janiak A, Wasmer E (2008) Mobility in Europe-Why it is Low, the Bottlenecks and the Policy Solutions. European Commission, Brussels

Jimeno J, Bentolila S (1998) Regional Unemployment Persistence (Spain, 1976-1994). Labour Economics 5(1):25-51 Kahanec M, Zimmermann K (2009) EU Labor Markets after Post-Enlargement Migration. Springer, Berlin, Germany

Karppinen J, Fernandez E, Krieger H (2006) Geographical Mobility: Challenges and Opportunities. In: Discussion paper presented at the conference to launch the European Year of Workers' Mobility 2006, Brussels, February 20-21, 2006

Koettl J (2009) Prospects for Management of Migration between Europe and the Middle East and North Africa: Demographic Trends, Labor Force Projections, and Implications for Policies of Immigration, Labor Markets and Social Protection. World Bank, Washington, DC

Koettl J (2013) Does Formal Work Pay in Serbia? The Role of Labor Taxes and Social Benefit Design in Providing Disincentives for Formal Work. Poverty and Exclusion in the Western Balkans:133-154, http://link.springer.com/ chapter/10.1007\%2F978-1-4614-4945-4 9\#

Koettl J, Weber M (2013) Does Formal Work Pay? The Role of Labor Taxation and Social Benefit Design in Providing Disincentives for Formal Work in the New Member States. Research in Labor Economics 34:167-204

Layard R (2005) Happiness: Lessons from a New Science. The Penguin Press, New York, NY

Lehmann H, Muravyev A (2010) "Labor Market Institutions and Labor Market Performance: What Can We Learn from Transition Countries?" Department of Economics Working Paper 714. Università di Bologna, Bologna

Manning A (1995) How Do We Know that Real Wages are Too High? The Quarterly Journal of Economics 110(4):1111-1125

Mansoor A, Quillin B (eds) (2006) Migration and Remittances: Eastern Europe and the Former Soviet Union. World Bank, Washington, DC

Montenegro C, Pagés C (2005) Who Benefits from Labor Market Regulations? Chile 1960-1998. In: Restrepo J, Tokman A, Loayza N, Schmidt-Hebbel K (eds) Labor Markets and Institutions, edition 1, volume 8. Central Bank of Chile, Santiago

Muenz R (2007) Aging and Demographic Change in European Societies: Main Trends and Alternative Policy Options. In: Social Protection Discussion Paper 0703. World Bank, Washington, DC

Nickell S (1997) Unemployment and Labor Market Rigidities: Europe Versus North America. Journal of Economic Perspectives 11(3):55-74

OECD (2004) OECD Employment Outlook. OECD, Paris

OECD (Organisation for Economic Co-operation and Development) (2007) Economic Survey of the European Union 2007. OECD, Paris

Packard T, Koettl J, Montenegro C (2012) In from the Shadow: Integrating Europe's Informal Labor. World Bank, Washington, DC

Parey M, Waldinger F (2011) Studying Abroad and the Effect on International Labor Market Mobility: Evidence from the Introduction of ERASMUS. Economic Journal 121(551):194-222

Pissarides C, Wadsworth J (1989) Unemployment and the Inter-regional Mobility of Labour. The Economic Journal 99 (397):739-755

Rebitzer J, Taylor L (1995) The Consequences of Minimum Wage Laws: Some New Theoretical Ideas. Journal of Public Economics 56(2):245-255

Rinne U, Zimmermann K (2012) Another economic miracle? The German labor market and the Great Recession. IZA Journal of Labor Policy 1:3

Rosen S (1997) Public Employment, Taxes and the Welfare State in Sweden. In: Freeman RB, Topel R, Swedenborg B (eds) The Welfare State in Transition: Reforming the Swedish Model. University of Chicago Press, Chicago 
Sharpe A, Arsenault J-F, Ershov D (2007) The Impact of Interprovincial Migration on Aggregate Output and Labour Productivity in Canada, 1987-2006. In: CSLS Research Report 2007-02. Centre for the Study of Living Standards, Ontario

Tatsiramos K (2007) Geographic Labour Mobility and Unemployment Insurance in Europe. Journal of Population Economics 22(2):267-283

United Nations (2010) World Population Prospects: The 2010 Revision. United Nations, New York, NY

United States Department of Labor (2011) International Comparisons of Manufacturing Productivity and Unit Labor Cost Trends. In: News Release USDL-11-1469, October 13., Available at http:/www.bls.gov/news.release/prod4.htm World Bank (2009) Ukraine Labor Demand Study. ECA Policy Note, World Bank, Washington, DC

World Bank (2010a) Demand for Skills in FYR Macedonia. ECA Policy Note, World Bank, Washington, DC

World Bank (2010b) Roma Inclusion: An Economic Opportunity for Bulgaria, Czech Republic, Romania and Serbia. ECA Policy Note, World Bank, Washington, DC

World Bank (2011a) Skills, Not Just Diplomas. Managing Education for Results in Eastern Europe and Central Asia. World Bank, Washington, DC

World Bank (2011b) World Development Report 2012: Gender and Development. World Bank, Washington, DC

World Bank (2012) In Search of Opportunities: How a More Mobile Workforce Can Propel Ukraine's Prosperity. World Bank, Washington, DC

Zimmermann K (2006) An Evaluation of the 'Hartz Reforms' in Germany. PowerPoint slides, Milan, February 3

10.1186/2193-9012-2-19

Cite this article as: Gill et al:: Full employment: a distant dream for Europe. IZA Journal of European Labor Studies 2013, 2:19

\section{Submit your manuscript to a SpringerOpen ${ }^{\circ}$ journal and benefit from:}

- Convenient online submission

- Rigorous peer review

- Immediate publication on acceptance

- Open access: articles freely available online

- High visibility within the field

Retaining the copyright to your article

Submit your next manuscript at $\boldsymbol{~ s p r i n g e r o p e n . c o m ~}$ 